\title{
Mass-transport deposits and reservoir quality of Upper Cretaceous Chalk within the German Central Graben, North Sea
}

\author{
Jashar Arfai ${ }^{1} \cdot$ Rüdiger Lutz $^{1} \cdot$ Dieter Franke $^{1} \cdot$ Christoph Gaedicke $^{1} \cdot$ Jonas Kley $^{2}$
}

Received: 23 October 2014 / Accepted: 6 May 2015 / Published online: 4 June 2015

(C) The Author(s) 2015. This article is published with open access at Springerlink.com

\begin{abstract}
The architecture of intra-chalk deposits in the 'Entenschnabel' area of the German North Sea is studied based on 3D seismic data. Adapted from seismic reflection characteristics, four types of mass-transport deposits (MTDs) are distinguished, i.e. slumps, slides, channels and frontal splay deposits. The development of these systems can be linked to inversion tectonics and halotectonic movements of Zechstein salt. Tectonic uplift is interpreted to have caused repeated tilting of the sea floor. This triggered large-scale slump deposition during Turonian-Santonian times. Slump deposits are characterised by chaotic reflection patterns interpreted to result from significant stratal distortion. The south-eastern study area is characterised by a large-scale frontal splay complex. This comprises a network of shallow channel systems arranged in a distributive pattern. Several slide complexes are observed near the Top Chalk in Maastrichtian and Danian sediments. These slides are commonly associated with large incisions into the sediments below. Best reservoir properties with high producible porosities are found in the reworked chalk strata, e.g. Danish North Sea, therefore MTDs detected in the study area are regarded as potential hydrocarbon reservoirs and considered as exploration targets.
\end{abstract}

Keywords Chalk Group · Entenschnabel · 3D seismic interpretation $\cdot$ Mass-transport deposits $\cdot$ Chalk reservoir

Jashar Arfai

jashar.arfai@bgr.de

1 Federal Institute for Geosciences and Natural Resources (BGR), Stilleweg 2, 30655 Hannover, Germany

2 Georg-August University Göttingen, Goldschmidtstr. 3, 37077 Göttingen, Germany

\section{Introduction}

The Late Cretaceous was a warm temperate to subtropical greenhouse period coinciding with a pronounced eustatic sea-level high stand (Surlyk et al. 2003). The latter resulted in a reduced influx of detritus and enabled pelagic sedimentation on the continental shelves, including the North Sea area (Surlyk et al. 2003). The water depth estimated for the Chalk Group probably ranged between a $100 \mathrm{~m}$ on the shelf and a few $100 \mathrm{~m}$ in the deep-water areas of the North Sea (Hancock 1975; Surlyk et al. 2003). The thickness of the Chalk Group in the Southern Permian Basin ranges between $<150$ and more than $1800 \mathrm{~m}$ showing regional maxima within the North Sea Central Graben (Vejbæk et al. 2010). After deposition, the chalk sediments were partly redistributed by bottom currents, which locally changed the sea floor morphology, resulting in the development of valleys, ridges, channels, moats, scours and drifts, indicating that the 'chalk sea' was a highly dynamic depositional environment (Surlyk et al. 2003, 2008; Lykke-Andersen and Surlyk 2004; Surlyk and LykkeAndersen 2007; Esmerode et al. 2008). Such erosional and sedimentary forms characterise allochthonous sediments, e.g. mass-transport deposits (MTDs), in contrast to autochthonous pelagic chalk that remained in place after deposition (Watts et al. 1980; Kennedy 1987; Taylor and Lapré 1987; Van der Molen et al. 2005; Esmerode et al. 2008; Back et al. 2011).

MTDs result from large-scale gravity-driven sediment mass-redistribution processes due to slope failure. In the North Sea Chalk, sediment redistribution by mass-transport processes is, e.g., described by slope instabilities leading to the movement of chalk sediment downslope into bathymetric lows of the North Sea Central Graben (Van der Molen et al. 2005; Back et al. 2011). Such MTDs can be 
identified, described and analysed on 3D seismic data from the German Central Graben. In this study, seismic facies interpretations are used to distinguish between autochthonous chalk, characterised by parallel and continuous reflections, and allochthonous chalk, characterised by irregular to chaotic reflection patterns.

As the demand for hydrocarbons increases and production from chalk reservoirs is in progress within, e.g., the Danish sector of the North Sea Central Graben, an increased understanding of intra-chalk depositional elements is needed.

However, in the German offshore sector, available data and knowledge of the Chalk Group are still limited due to its hitherto restricted significance as a hydrocarbon reservoir in this region. To date, no detailed seismic interpretation of the Chalk Group is published for the Entenschnabel area. In contrast, in areas where chalk deposits represent an important hydrocarbon-producing interval such as in the Norwegian, Danish and Dutch North Sea sectors, the Chalk Group is studied in more detail. The Maastrichtian and Danian Chalk in the Danish, Dutch and the Norwegian North Sea sectors revealed favourable structural and petrophysical conditions, and some of them are proven, oil-bearing reservoirs (Megson 1992; Jeppesen 1994; Bramwell et al. 1999; Surlyk et al. 2003; Van der Molen et al. 2005; Gennaro et al. 2013). It is yet an open question whether the Chalk Group in the German Central Graben is a prolific exploration target.

This paper provides new 3D seismic-based insights into the chalk environment offshore north-western Germany by presenting geological details of intra-chalk MTDs and discussing their potential as hydrocarbon reservoirs.

\section{Geological setting}

The Entenschnabel area offshore Germany (Fig. 1a) is characterised by four major structural elements, the Schillgrund High, the Central Graben, the Step Graben System and the Mid-North Sea High (Fig. 1b). These major structural elements are internally characterised by a number of minor structural features such as the John Graben and the Clemens Basin (Fig. 1b). The Entenschnabel area underwent a multiphase tectonic evolution leading to complex rift structures, with the Central Graben as the main structural element (Arfai et al. 2014; Fig. 1b). The Central Graben offshore Germany is dominated by halokinesis of Zechstein salt resulting in the development of salt pillows and diapirs with associated rim-synclines (Schulz-Ela et al. 1993; Arfai et al. 2014; Fig. 1b). The intensity of salt movement varies strongly during geological periods, but generally increases towards the southern realm of the Entenschnabel (Arfai et al. 2014; Fig. 1b). The initiation of the Central Graben as a half-graben system took place not later than Early Triassic (Sclater and Christie 1980; Barton and Wood 1984). The Middle Jurassic thermal doming event (Ziegler 1990) led to erosion of the Triassic-Mid-Jurassic sediments (Underhill and Partington 1993; Graversen 2002, 2006). The Late Jurassic is marked by a major extensional phase in combination with extensive reactivation of diapirism which was initiated during the Late Triassic. Analyses of rim-synclines reveal that most of the salt structures had their main growth phase during the Late Jurassic (Arfai et al. 2014). Rifting activity decreased gradually during the later parts of the Early Cretaceous. This time is marked by post-rift thermal relaxation and subsidence in combination with a steady eustatic sea-level rise (Ziegler 1990). The latter resulted in the progressive flooding of landmasses surrounding the Early Cretaceous North Sea Basin (Ziegler 1990). At the end of the Early Cretaceous, sea level exceeded present-day levels by 100-300 m (Albian transgression; Hancock 1975) which enabled initial deposition of the Chalk Group in the North Sea Basin (Ziegler 1990).

The structural inversion phases during Late Cretaceous and the Early Palaeogene were caused by compressional tectonics affecting the whole of the North Sea region including the German Central Graben (Liboriussen et al. 1987; Mogensen and Jensen 1994; Vejbæk and Andersen 2002). Tectonic inversion in the North Sea is commonly explained by the collision of Europe with Africa (Ziegler 1990). This tectonic phase dominantly affected the eastern border faults of the German Central Graben mainly during Turonian-Santonian (e.g. Schillgrund Fault, Arfai et al. 2014; Fig. 1b). In the same time, tectonic activity was accompanied by halotectonic movements of the Zechstein salt which significantly influenced the Upper Cretaceous sedimentary distribution. Vertical tectonic uplift is regarded as potential trigger for slope instability and thus for gravitational mass flows within the Central Graben area (Van der Molen et al. 2005). Inversion tectonics waned at the end of the Campanian, and from the Maastrichtian to the Palaeocene, only minor tectonic activity is documented in the study area.

\section{Database and methodology}

\section{Database}

Four 3D seismic reflection surveys covering approximately $4000 \mathrm{~km}^{2}$ supplemented by 2D seismic data were used for the construction of thickness and depth maps of prominent stratigraphic units and for the interpretation of intra-chalk deposits (Fig. 1a). Seismic interpretation was made on time-migrated data with a bin size of $12.5 \mathrm{~m}$ and a sampling rate of $4 \mathrm{~ms}$. In support of seismic reflectivity data, 
Fig. 1 a Location map and available data in the study area. The Entenschnabel covers an area of approximately $4000 \mathrm{~km}^{2}$ in the north-western distal part of the German North Sea. Water depth in the Entenschnabel ranges between 20 and $60 \mathrm{~m}$. b Overview of the structural pattern and salt structures in the Entenschnabel area. Major structural elements and subordinate features include: 1 Outer Rough Basin, 2 Mads Graben, 3 Hans Graben, 4 John Graben, 5 Clemens Basin, 6 Mads High, 7 Hans High, 8 Outer Rough High, 9 Schillgrund High, 10 Mid-North Sea High [modified after Arfai et al. (2014)]. Dashed red lines indicate the location of illustrated seismic profiles in Fig. 6
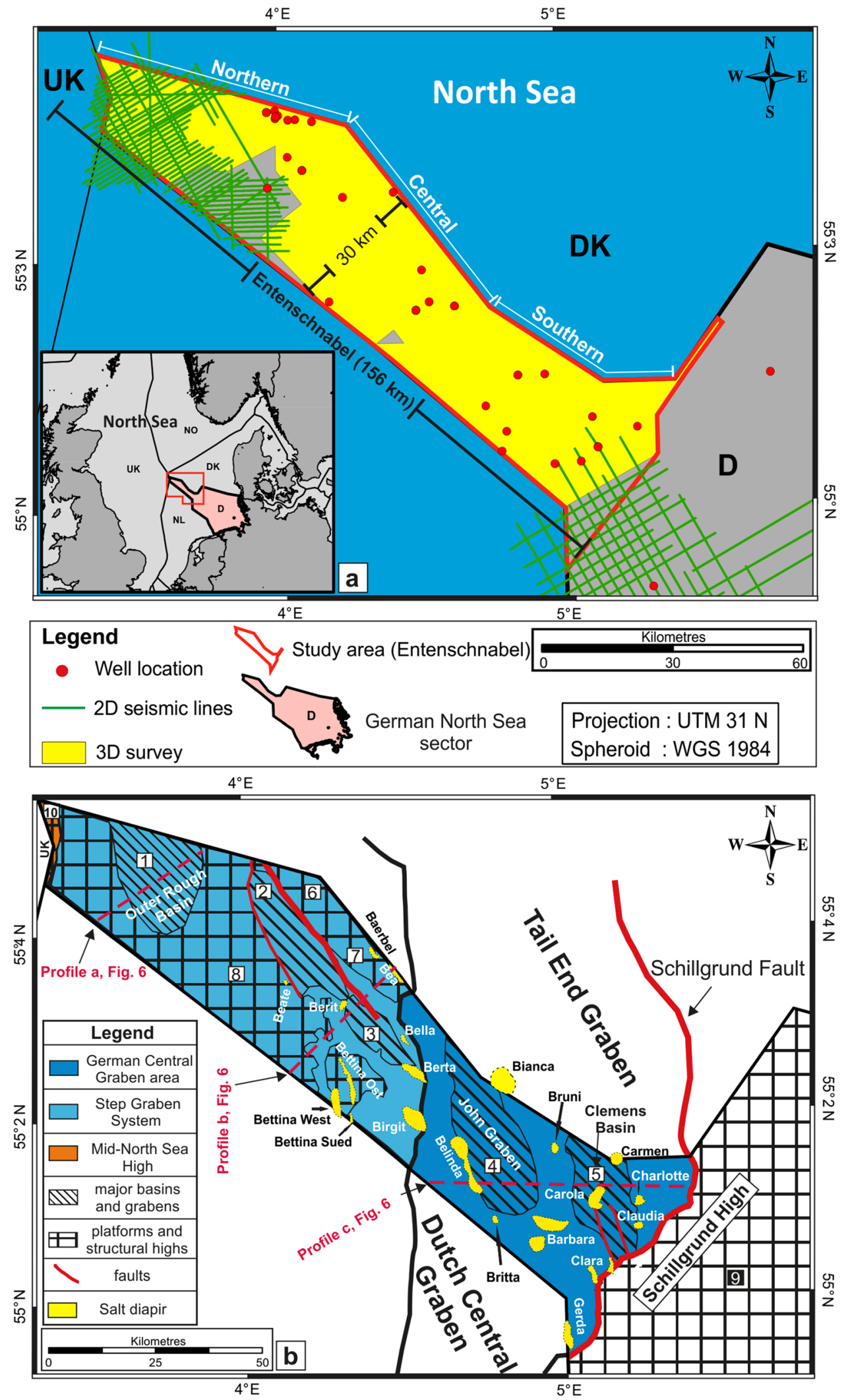
other seismic attribute volumes (variance and chaos) were calculated and used for detailed structural and seismic-sedimentological analysis. Stratigraphic correlation and age approximation of MTDs were achieved by the integration of industrial wells into the seismic data. The localisation of wells used in this study can be seen in Fig. 1a. Confidential information of both industry wells and seismic data was only accessible for scientific purposes. The presentday stratigraphic and structural framework is adopted from Arfai et al. (2014).

\section{Methodology and definition of MTDs}

Many different classification schemes and specific nomenclatures in former and recent studies exist for intra-chalk erosional surfaces which are influenced by slope instability in the North Sea (Watts et al. 1980; Kennedy 1987; Taylor and Lapré 1987; Surlyk et al. 2003; Van der Molen et al. 2005; Back et al. 2011). In this study, we use the generic term MTDs to describe relocated sediments caused by submarine slope failures. The latter occurs when the downslope driving forces acting on sediments composing the sea floor are greater than the forces acting to prevent their movement (Lee et al. 2007). MTDs are distinctive in deep-water depositional systems and are marked in the studied data set by complex seismic facies associations showing distinct morphologies, infill geometries, dimensions and orientation which will be described in a later section. The structural style of MTDs encountered varies with changes of environmental parameters. For the identification of MTDs, standard seismic interpretation techniques (Mitchum et al. 1977; Catuneanu et al. 2011) were supplemented with studies on seismic geomorphology and stratigraphy of depositional environment in deep-water settings (Posamentier 2003; Posamentier and Kolla 2003; Frey-Martínez et al. 2005, 2006; Lee et al. 2007; Kolla et al. 2007; Bull et al. 2009). Erosional incisions and unconformities were mapped using seismic cross sections and time slices (variance cube). After mapping the basal incision and the top of each MTD in the time domain (TWT), the reflectors were depth converted by the employment of a linear velocity approach for several layers except for the Zechstein salt (Arfai et al. 2014). Finally, their volumes were measured. MTDs contain a wide spectrum of gravity-driven depositional elements. Four key elements were observed, namely slumps, slides, submarine channels and frontal splay systems:

- Slumps include the relocation of plastically reworked sediment masses at slope gradients downwards into the bathymetric lows of basin floors. In seismic profiles, the internal structure of these depositional elements is typically chaotic due to deformed sediments preserved above a basal shear surface (Watts et al. 1980; Kennedy
1987; Frey-Martínez et al. 2005; Lee et al. 2007; Bull et al. 2009). The plane that defines the upslope margin of MTDs is referred to as headwall scarp (Bull et al. 2009).

- In contrast to slumps, slide complexes are characterised by movement and emplacement of internally undeformed sediment masses along discrete slip planes (Kennedy 1987; Frey-Martínez et al. 2006; Lee et al. 2007).

- Straight to meandering submarine channel systems develop at submarine slopes when turbidity currents are present (Catuneanu 2003; Lee et al. 2007; Kolla et al. 2007). They characterise the downward transport of a relatively dilute suspension of sediment grains that are supported by an upward component of fluid turbulence (Lee et al. 2007). Channel bases are characterised in seismic cross sections by incisions into the underlying substrata and ranging from straight to high sinuosity as visible on time slices (Posamentier 2003; Posamentier and Kolla 2003).

- Frontal splay complexes (channelised lobes) are characterised by a network of numerous, small and shallow channel systems with varying directions (Posamentier 2003; Posamentier and Kolla 2003). Channels associated with the splay complex range from straight to highly sinuous (Posamentier 2003; Posamentier and Kolla 2003).

\section{Results}

\section{Seismic observations}

\section{Cross-sectional geometry and seismic infill facies}

Incisions in seismic cross sections within the Chalk Group are U-, V-, W-shaped or tabular and erosionally truncate underlying strata (Fig. 2). The infill of most incisions is characterised by typical onlap structures (Fig. 2a, b). In other cases, the infill shows a complex pattern with inclined reflections mainly observed in large erosional U-shaped or tabular incisions (Fig. 2a-e). Rarely, the infill is characterised by a transparent fill facies which is marked by blurred reflections (Fig. 2h). Diffuse images (diffuse infill facies) or the absence of reflections recognised directly below the Danian succession in tabular or W-shaped depressions may be indicative of infill geometries below seismic resolution or very low acoustic impedance contrasts (Fig. 2 c, d, i). In places, U-shaped depressions are dominated by a 'divergent' fill facies which is characterised by a wedge-shaped reflection configuration that is thickest near the centre of the incisions (Fig. 2j). Slope angles of incisional features vary in the study between $5^{\circ}$ and $29^{\circ}$ (Fig. 2a-j). 


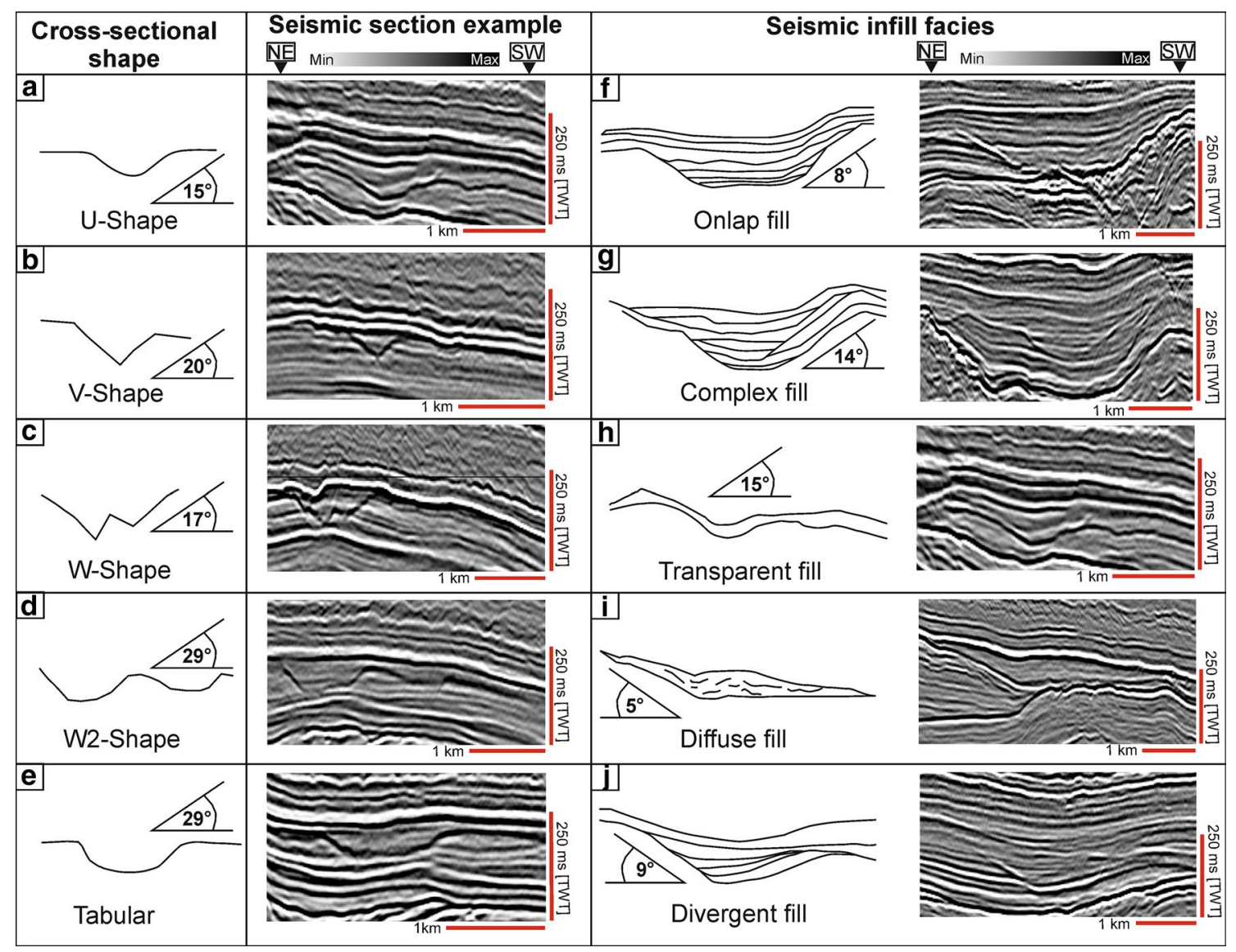

Fig. 2 a-e Reflection pattern, style and infill of incisions in seismic cross sections. In seismic cross sections, depositional elements are subdivided into U-, V- and W-shaped or tabular incisions (a-e), induced by erosional truncation of the immediately underlying sedi-

\section{Dimensions and orientation}

The incisions in general all appear as elongated features and in places as spherical forms on time slices. The absolute length of the features varies from 2 to $10 \mathrm{~km}$ and widthwise they range from 0.1 to $4.0 \mathrm{~km}$. The internal depth of the incisional structures varies from 20 to $150 \mathrm{~m}$, but most of the depressions are between 100 and $150 \mathrm{~m}$ deep. A typical incision has a volume of some $0.5 \mathrm{~km}^{3}$. The orientation of the long axis was estimated for all incisions. The large majority of the incisions strike between NNWSSE and NW-SE. In places, N-S and NE-SW-oriented features are visible on time slices.

\section{Seismic subdivision}

Five major stratigraphic units, the Cenomanian, TuronianSantonian, Campanian, Maastrichtian and Danian, were interpreted subdividing the interval of interest into five units (Fig. 3). The 'base Upper Cretaceous' negative polarity reflector defines the bottom of the Chalk Group (Figs. 3, ments. $\mathbf{f}-\mathbf{j}$ The incision infill patterns are subdivided into five seismic facies as illustrated: 'onlap' fill, 'complex' fill, 'transparent' fill, 'diffuse' fill (low amplitude and no clear reflection) and 'divergent' fill. Terminology adapted from Mitchum et al. (1977)

4a). The prominent 'base Palaeogene' reflector delimits the top of the Chalk Group and occurs at depths ranging between 850 and $2900 \mathrm{~m}$ (Figs. 3, 5). The Chalk Group can be easily identified in sonic logs by the significant velocity contrast between the high-velocity Chalk carbonates and the encasing Palaeocene and Lower Cretaceous shales. In gamma-ray logs, Upper Cretaceous sediments are generally characterised by conspicuously low readings, which are a result of very small amounts of clay (Fig. 4).

The internal configuration of the Chalk Group shows variations in seismic facies pattern (Fig. 6). In the northwestern and central part of the Entenschnabel, the seismic sequences of the autochthonous Chalk Group generally show parallel and continuous reflections with high to medium amplitudes (Fig. 6a, b). In the southern Entenschnabel, the German Central Graben area, the Chalk Group is often characterised by large-scale erosional and redepositional phenomena (Fig. 6c). Here, the seismic response of the Chalk is characterised by a dominantly discontinuous to chaotic reflection pattern, e.g., in the Turonian-Santonian unit. Characteristic features include reflectors that can only 

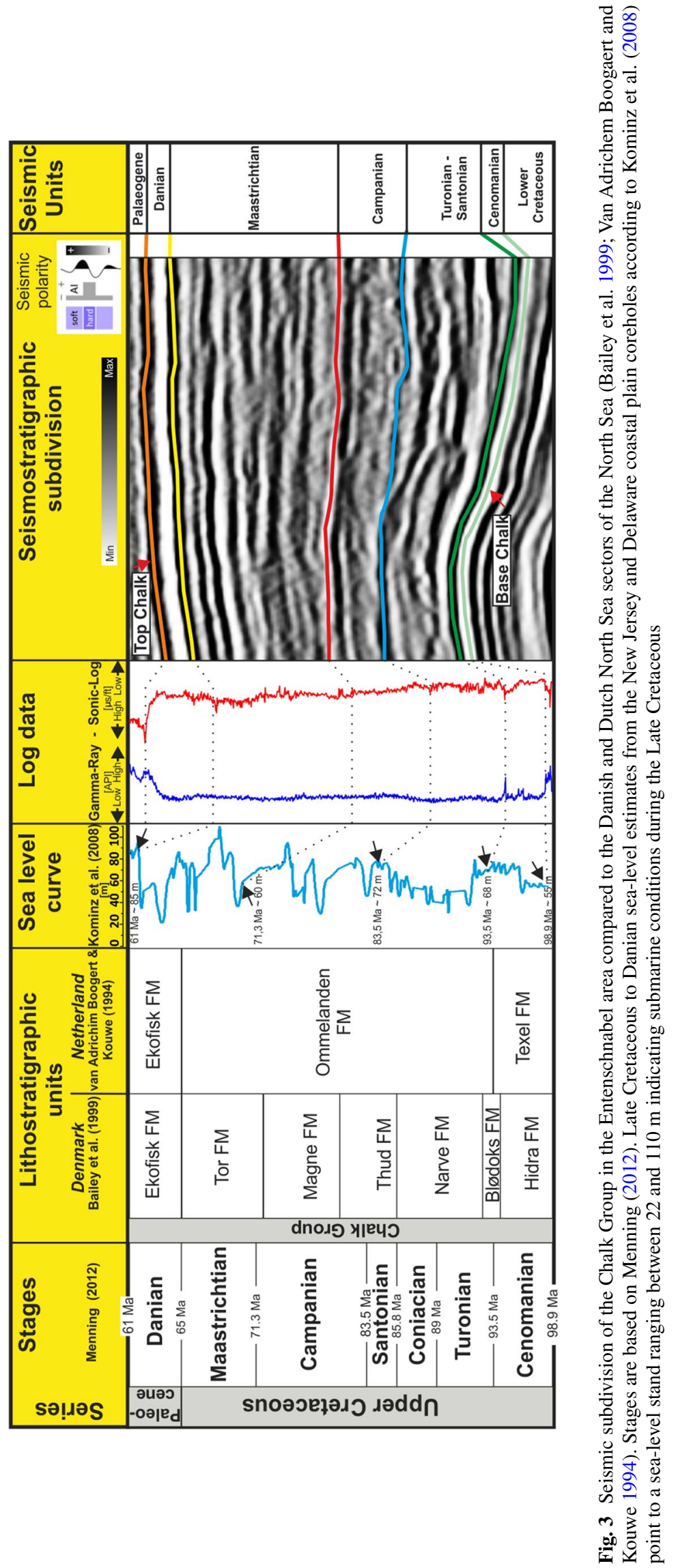
Fig. 4 a Depth map of the base Upper Cretaceous. b Thickness map of the Chalk Group between the base Upper Cretaceous and the base Lower Palaeogene [modified after Arfai et al. (2014)]
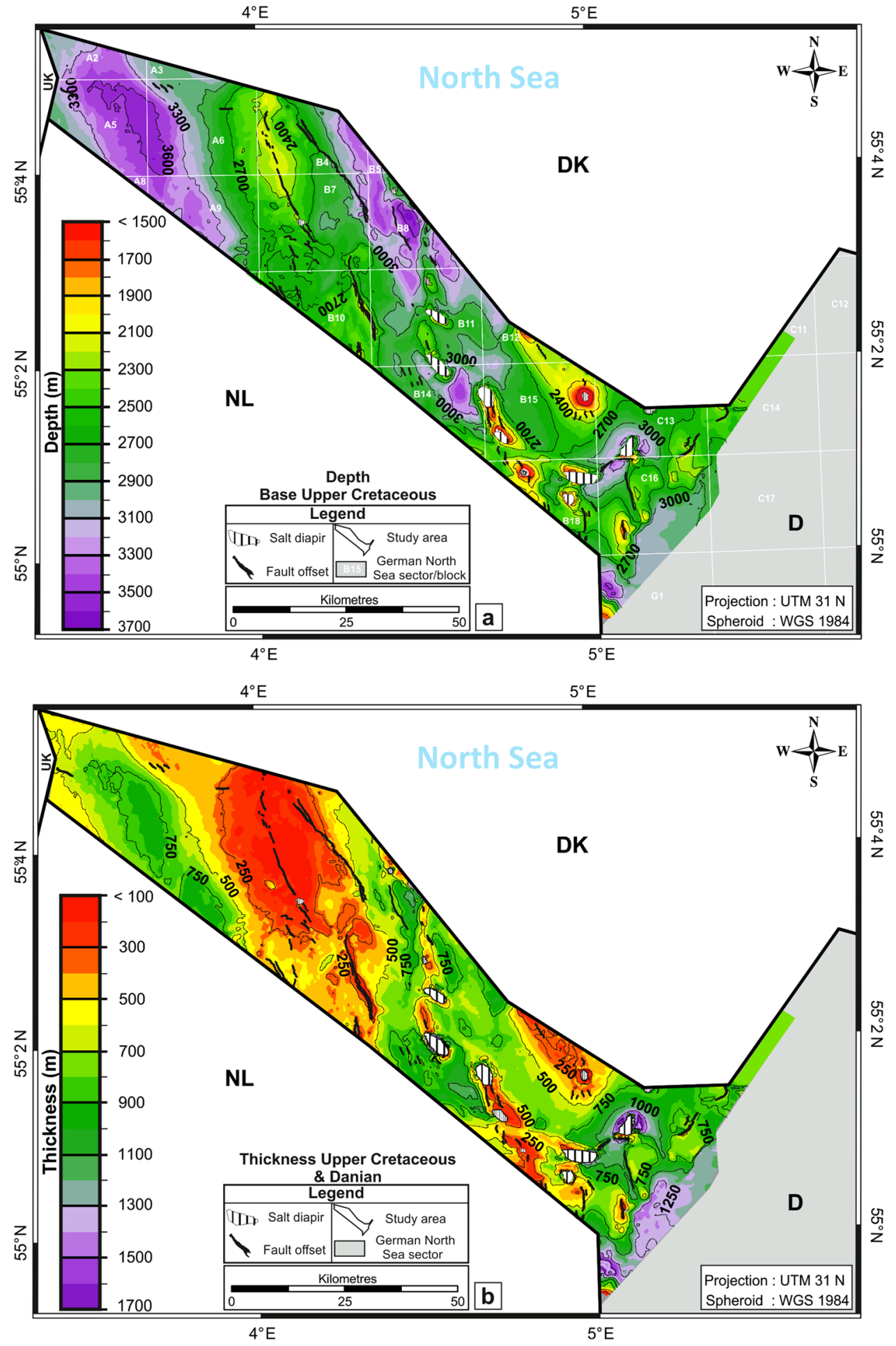

be followed over a few kilometres. The maximum thickness of up to $1700 \mathrm{~m}$ of Chalk occurs on the Schillgrund High which is the graben shoulder of the Central Graben. Inversion during the Upper Cretaceous pushed this graben shoulder down and created accommodation space for the deposition of thick chalk sediments (Figs. 1b, 4b).

\section{Cenomanian unit}

The base of the Cenomanian unit (light green; Ce; Figs. 3, 6) coincides with the top of the Lower Cretaceous succession and can easily be identified in the study area (Fig. 6). The present-day depth of the base Upper Cretaceous ranges 
Fig. 5 Depth map of the base Palaeogene [Top Chalk; modified after Arfai et al. (2014)]

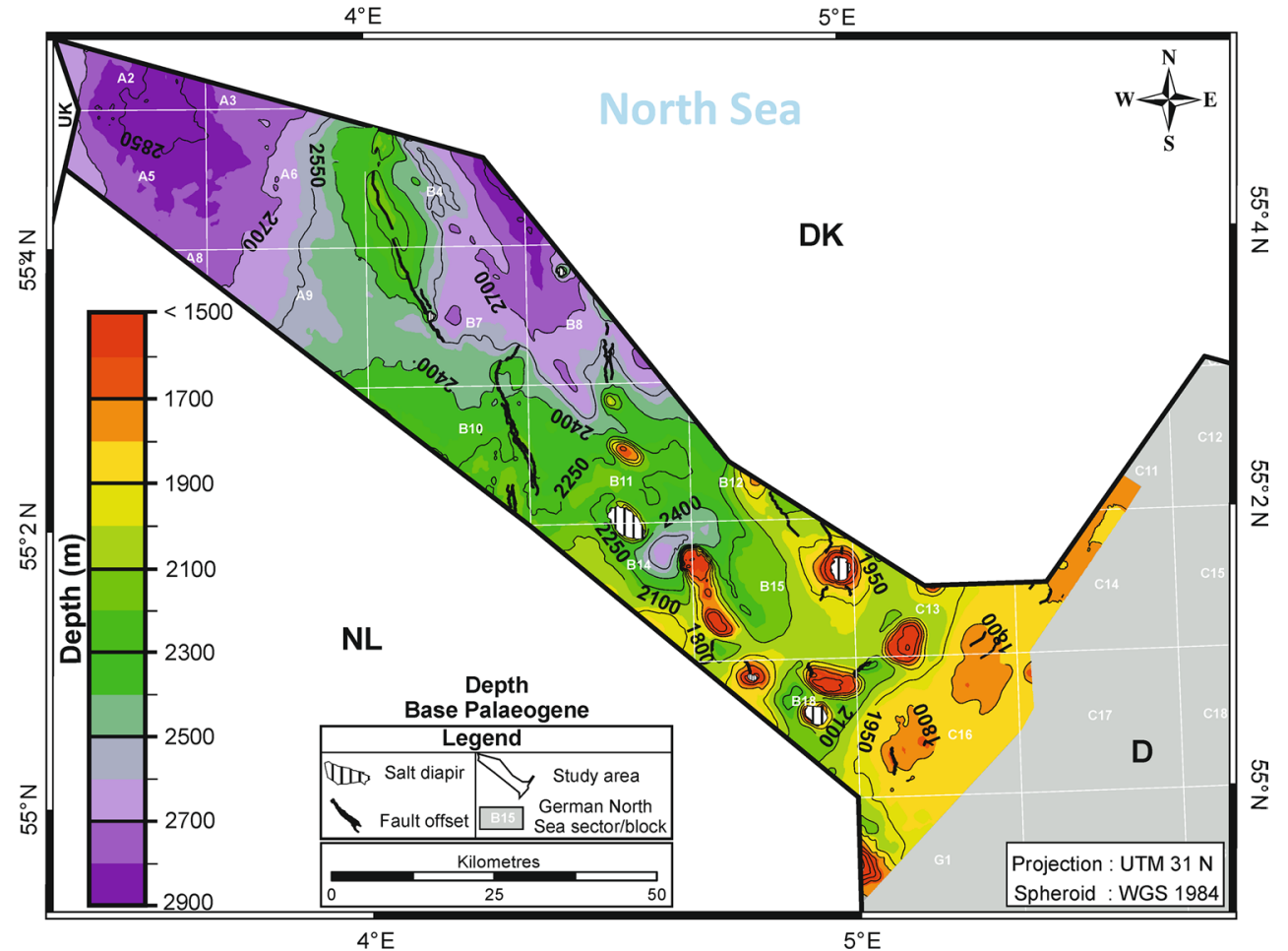

from $<1500$ to more than $3600 \mathrm{~m}$. Thickness increases towards the north-west into the Outer Rough Basin and towards the north-east close to the border of the Danish sector (Figs. 1b, 6a). In sonic logs, the transition at the base of the Cenomanian into the underlying Lower Cretaceous succession is indicated by a strong shift towards lower seismic velocities. The upper boundary of the Cenomanian unit is marked by a distinct spike in the gamma-ray log reflecting the transition into the Plenus Marl Member. The areal extent of the sequence is outlined on the base Chalk Group (base Cenomanian) depth map and is only locally controlled by erosion (Fig. 4a). The base Cenomanian appears in large parts of the study area to be a continuous prominent reflector with a negative seismic polarity. The reflection image varies between high amplitudes in the southern and central Entenschnabel and intermediate amplitudes in the north-western Entenschnabel (Fig. 6). In the southern part of the Entenschnabel, extensive deformation by salt doming and faulting resulted in a much less clearly developed, weak and discontinuous reflection pattern (Fig. 6c).

The internal configuration between the base Cenomanian and the base Turonian consists of parallel and continuous reflectors with intermediate reflection amplitudes.

\section{Turonian-Santonian unit}

The base of the Turonian-Santonian unit (dark green; TuSa; Figs. 3, 6) displays in the southern study area a highamplitude, continuous reflector with a positive seismic polarity. The only significant peak in the gamma-ray and the sonic log curve within the Chalk Group reflects the transition from the Cenomanian into the Turonian unit (Fig. 3). The base Turonian is only preserved in the southern and locally in the central Entenschnabel area and ranges in a present-day depth between 1700 and $3540 \mathrm{~m}$. The present areal extent of this reflector is controlled by erosional truncation by overlying sequences. Within the Turonian-Santonian chalk interval, a large, chaotic seismically discontinuous unit occurs in the south-eastern study area at a depth ranging between 2500 and $2900 \mathrm{~m}$. The discontinuous unit is clearly affected by salt tectonics (Fig. 7) which is documented by diapirs actively piercing intra-chalk surfaces during chalk deposition (Fig. 7a). The reflection package attains a thickness of up to $200 \mathrm{~m}$ and can be traced over a distance of approximately $30 \mathrm{~km}$ (Fig. 7a, b). Seismic time slices (variance, $2220 \mathrm{~ms}$; TWT) and seismic cross sections display a variety of morphologically prominent discontinuity features indicating a markedly dynamic palaeosea floor relief (Fig. 7a). Deformed areas show locally distinct angular unconformities which are related to halotectonic movements and the development of rim-synclines. Visible chaotic, hummocky and discontinuous reflectors of this unit are possibly prone to sediment erosion and suggestive for redistribution by mass-transport processes showing partly high amplitudes. In addition, disorganised deposits display an internal pattern of thrusts of varying directions which indicate compressional deformation during the transport processes (Fig. 7b). Well-log interpretation reveals that the 


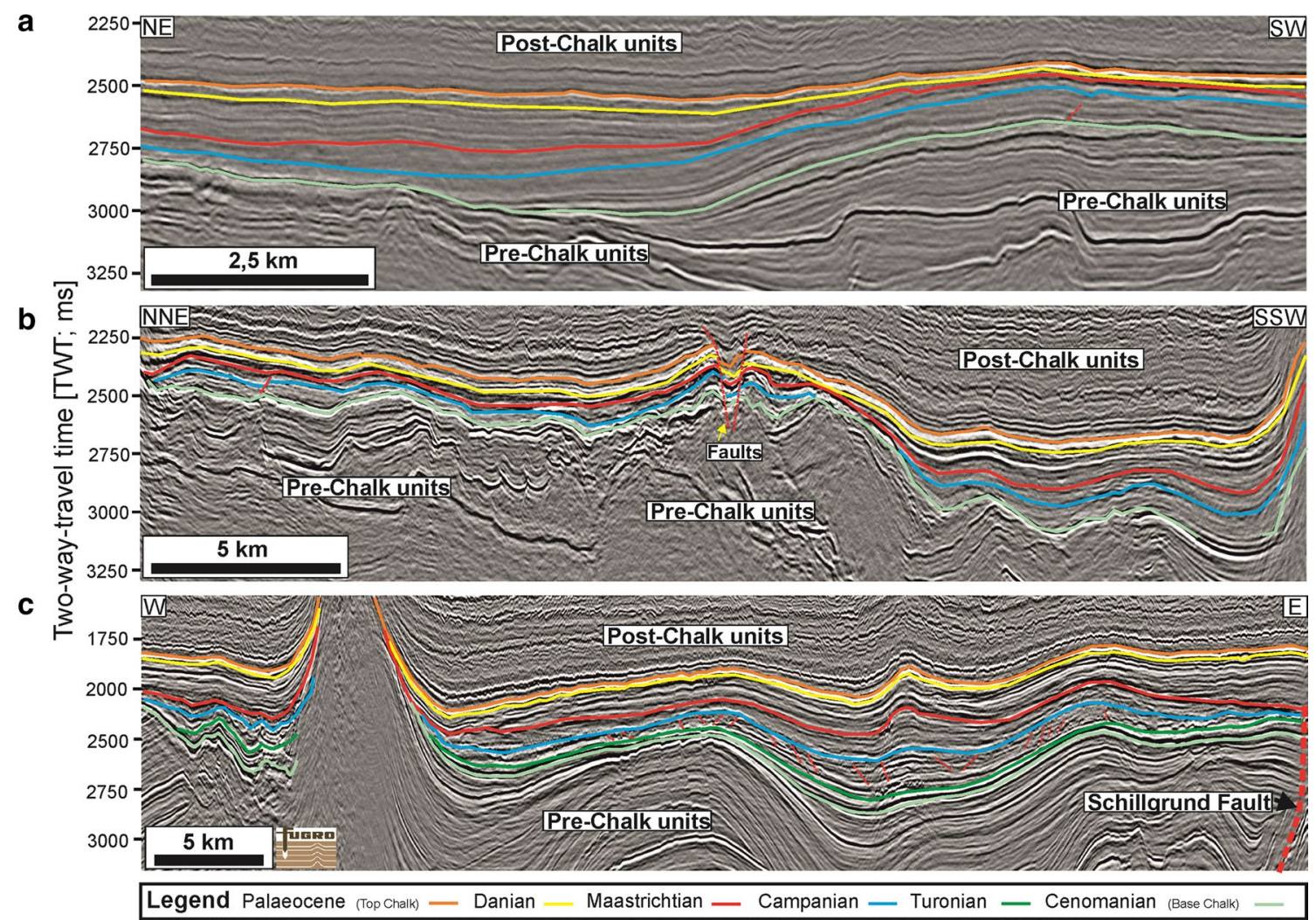

Fig. 6 a Seismic profile crosses the Outer Rough Basin mainly formed by subsidence of post-dating concordant chalk deposition. b Profile 2 illustrates the central Entenschnabel area and covers the southern part of the Step Graben System. c Profile 3 is located in the southern part of the study area that is characterised by chaotic, seismically discontinuous unit mainly developed during the Turonian-

prominent 'near base Turonian' reflector is a mudstone layer which acts as a basal shear surface (Figs. 3, 7b). This layer forms a continuously traceable seismic reflector that separates the highly deformed and chaotic seismic units from the underlying undeformed Cenomanian unit. Headwall scarps of slope failures are in places imaged in the seismic profiles (Fig. 7a, b). Based on the shape, surface morphology and internal reflection character, the entire depositional system can be interpreted as a slump deposit. The same discontinuous and disorganised reflection pattern above the base chalk level visible in the vicinity of salt diapirs also concentrates on tectonic active realms of the German Central Graben where inversion tectonics affected the binding faults of Clemens Basin and the Schillgrund Fault (Figs. 1b, 7c). Here, chaotic and deformed seismic responses suggestive of isolated, small-scale mass-transport complexes are visible. Chaotic seismic responses correlate with the Turonian-Santonian unit, while stratigraphically younger sediments above this interval remained mainly undeformed (Fig. 7a, b).

In the southernmost part of the study area, numerous parallel-trending slightly sinuous to almost linear variance
Santonian times. Within the Turonian-Santonian unit, several generations of channel-like features cut into the underlying sediments. The anticlines visible within the eastern part of the profile are a result of both intra- and post-chalk compressional movements and developed at the adjacent reversed Schillgrund Fault. Red dashed lines indicate fault structures. For location of the profiles, see Fig. 1b

attribute features that extend in a NW-SE direction are encountered (Fig. 8). In seismic cross sections, the individual bases of these elongate erosional features incise into the MTDs (slump deposits) of the Turonian-Santonian unit by reflections which delineate truncations into the underlying strata (Fig. 8a, b). These seismic discontinuities resemble weak and less incised channels or channel segments showing a straight to moderate sinuosity (Fig. 8a, b). There are also a variety of linear and curved features resembling channel systems that are oriented in different directions, with trends mainly south-eastward. The combination of time slices and cross sections indicates the channels as ranging in width from 350 to $<70 \mathrm{~m}$, and they attain a maximum length of approximately $10 \mathrm{~km}$ within the German Central Graben area (Fig. 8b, c). Incised channel systems display erosional sedimentary processes and are generated by downslope-oriented turbidity-current flows within them thus transporting chalk sediments farther to the depocentres. On time slices, some of these channel systems terminate in shallow and closed spherical forms characterised in cross sections by tabular and shallow truncations into the 

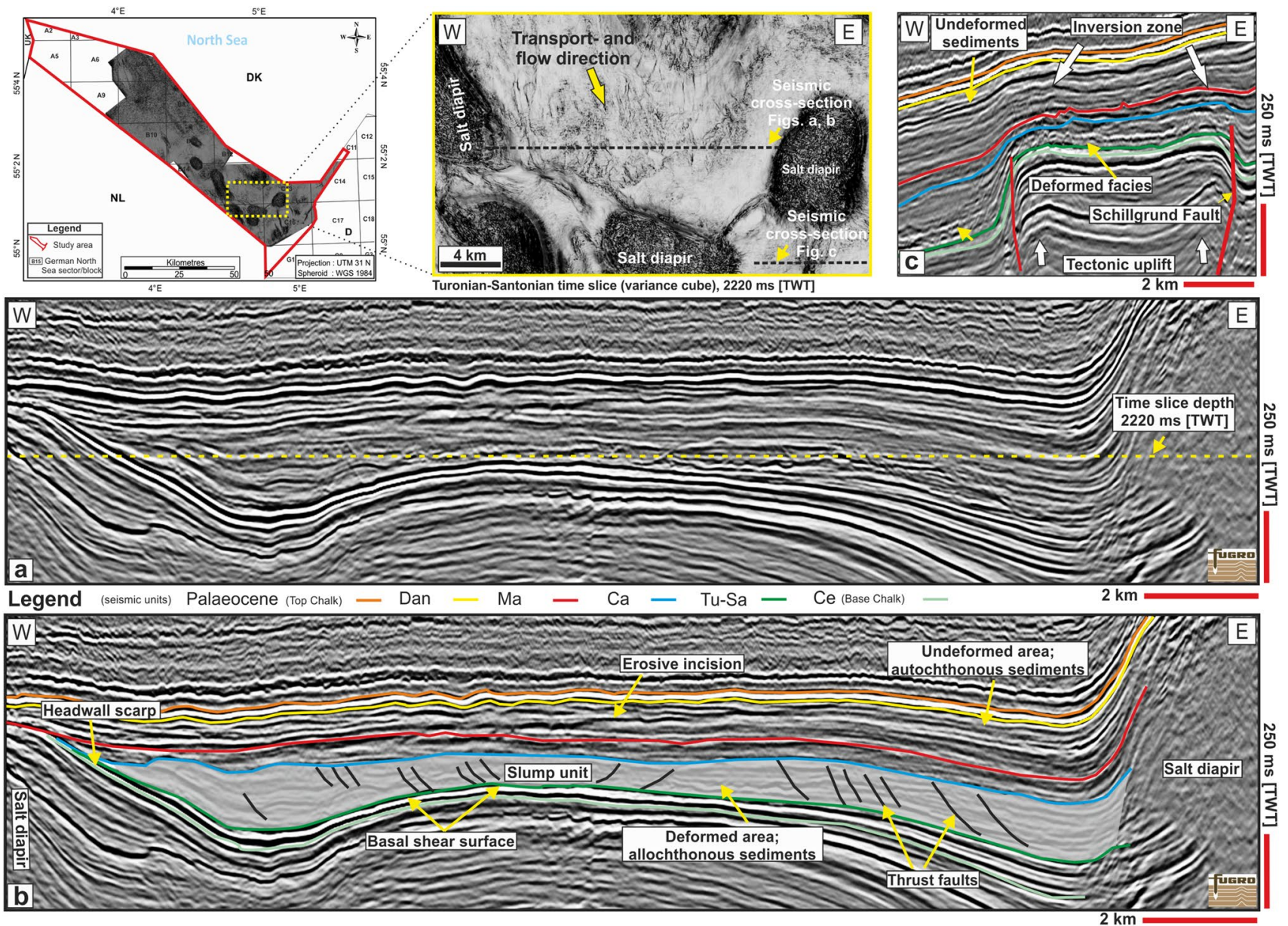

Fig. 7 Slump deposits comprising the Turonian-Santonian unit. a Example (representative) of a seismic cross section showing a large chaotic sediment complex in the south-eastern study area at a depth ranging between 2500 and $2900 \mathrm{~m}$. b Interpreted seismic cross section. The time slice covering the same area of the seismic cross section at a depth of $2200 \mathrm{~ms}$ [TWT] indicates a marked irregular sea

underlying sediments (Fig. 8a). These features seem to be fed by channels and can be interpreted as depositional lobes developed in the front of channels systems covering an area of up to $0.6 \mathrm{~km}^{2}$ (Fig. 8a).

Within the south-easternmost study area, the TuronianSantonian unit is dominated by numerous branched and parallel-trending lineaments preserved above the basal shear surface (base Turonian; Fig. 8a). These systems cover an area of approximately $40 \mathrm{~km}^{2}$ and are visible at a depth of $2190 \mathrm{~ms}$ (TWT; approximately $2280 \mathrm{~m}$; Fig. 9a). Branched features are moderately to highly sinuous with a markedly irregular topography, reflecting a sequence of small U- or V-shaped incisions in seismic cross sections (Fig. 9b). Seismically, these deposits are characterised by high-amplitude, slightly discontinuous reflections (Fig. 9b). Based on the shapes on time slices (see inset Fig. 9a) which was supplemented with seismic cross sections, this system floor relief affected by five surrounding salt diapirs (above). c Seismic cross section where inversion tectonics affected the German Central Graben during the Late Cretaceous. This area indicates same chaotic seismic responses which are also visible in the vicinity of salt diapirs within the German Central Graben

may be classified as a frontal splay complex associated with a network of small and shallow channels which are arranged in a distributive pattern sensu (Posamentier 2003; Posamentier and Kolla 2003). At the terminations of some channels, elongated lineaments are visible on time slices showing small V-shaped incisions into the sediments below which can be interpreted as grooves as described also by Posamentier and Kolla (2003; Fig. 9a).

\section{Campanian unit}

The lower boundary of the Campanian (blue line; Ca; Figs. 3, 6) unit is defined by the base Campanian reflector (ranging in a present-day depth between 1500 and $3530 \mathrm{~m}$ ) with a positive seismic polarity (Fig. 3). The base Campanian represents the even top of the underlying sequence with chaotic and discontinuous reflections in the southern 


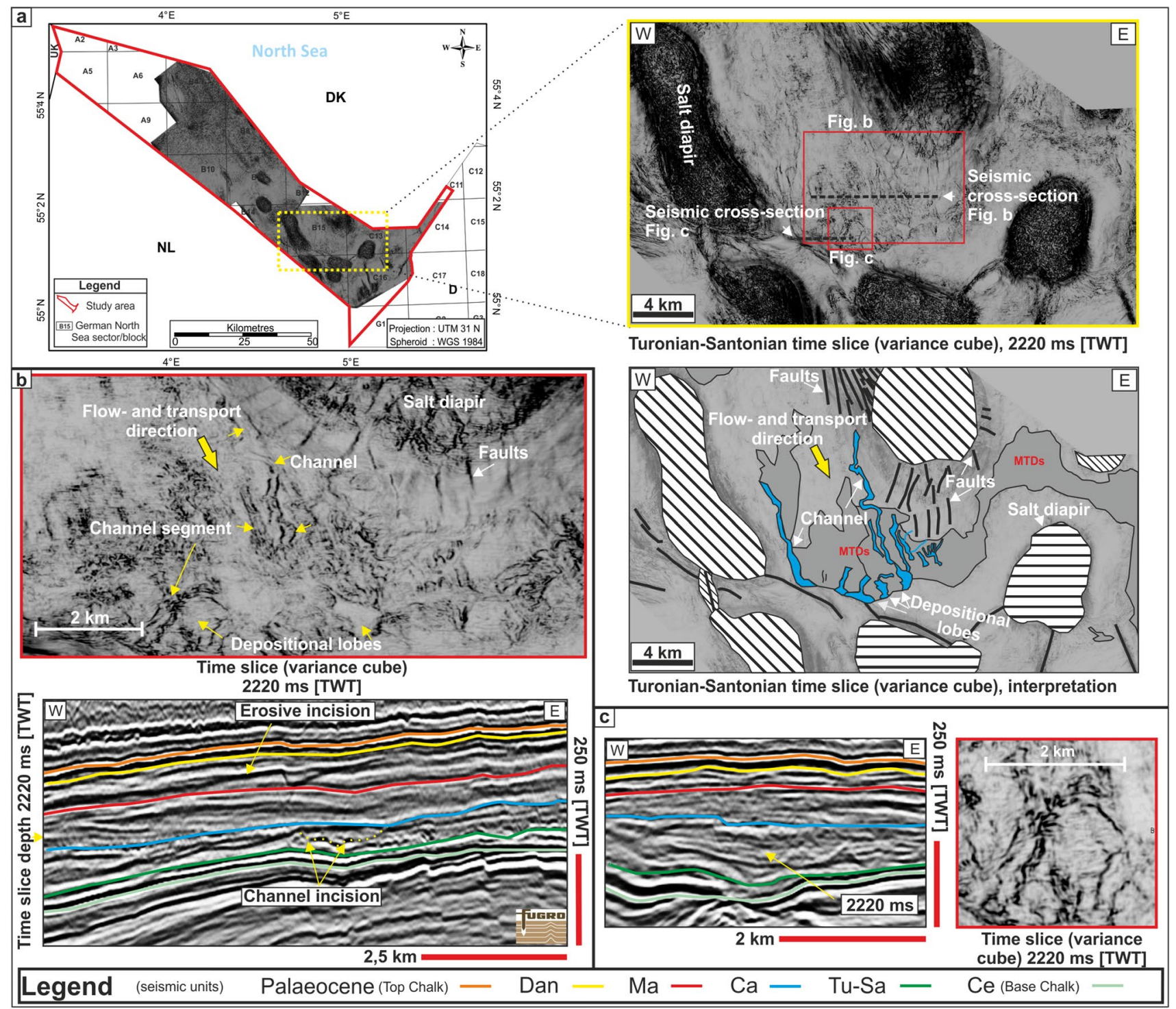

Fig. 8 a The area where the MTDs were interpreted within the Turonian-Santonian unit is also dominated by localised erosion by turbidity-induced channel systems. These systems are characterised by straight to sinuous, elongated and parallel-trending features. b, c In seismic cross sections, channel bases are developed by incisions or

Entenschnabel (Fig. 6c). In this part, the internal configuration of the Campanian succession predominantly consists of subparallel to parallel reflections with low amplitudes (Fig. 6c). Locally, a hummocky and chaotic pattern is visible. However, the lowermost and uppermost part of the unit shows aligned high-amplitude and parallel reflections, especially in depressions and lows along several profiles (Fig. 6). Towards the north-west, the sequence is dominated by erosional truncations of the overlying sediments of Upper Campanian-Lower Maastrichtian (Fig. 6a). In undeformed areas in the north-western part, the internal geometry is dominated by weak but parallel and continuous truncations into the underlying strata. On time slices, some of these channels terminate in shallow and closed spherical depositional lobes. Channel systems attain widths from 350 to $<70 \mathrm{~m}$ and reach a maximum length of approximately $10 \mathrm{~km}$

reflections. Isolated bands of parallel and high-amplitude reflectors are exposed (Fig. 6a). The unit is locally eroded and cut by moats and channel-like features. Where the Campanian unit is dominated by salt movement and uplift processes, the base of the Campanian unit forms an erosional unconformity which is onlapped by overlying reflectors (Fig. 6).

A system of NNW-SSE-oriented incisions is located between two salt diapirs visible on the time slice (Fig. 10a). In seismic profiles, the top of the incision fill is defined by the 'base Maastrichtian' reflector, while the lower boundary is formed by the base of the Campanian unit. The 


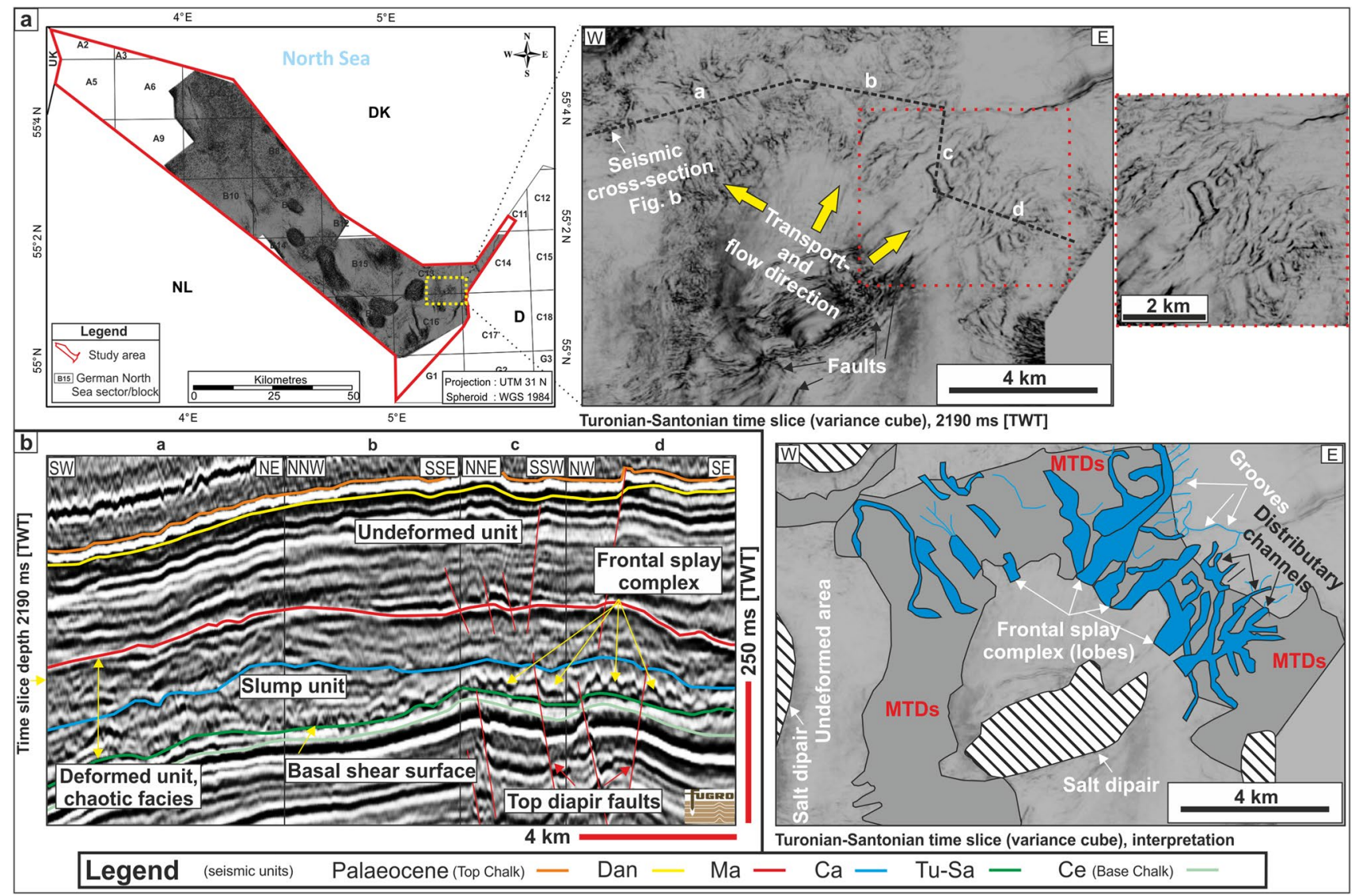

Fig. 9 a In the south-easternmost study area, distributary channel systems covering an area of approximately $40 \mathrm{~km}^{2}$ are identified on time slices (e.g. $2190 \mathrm{~ms}$; TWT; approximately $2280 \mathrm{~m}$ ). The channels are characterised by branched and parallel-trending lineaments showing trends ranging from straight to a moderate sinuosity. b In seismic cross sections, channels are characterised by a sequence of less incised U- or V-shaped truncations which appear within the lower section of the Turonian-Santonian unit reflectors incision is mostly $\mathrm{U}$ - to tabular-shaped showing a typical onlap fill facies with internal depth of approximately $100 \mathrm{~m}$. The width is approximately $1.7 \mathrm{~km}$, and the structure extends up to $1.2 \mathrm{~km}$ (Fig. 10b, c). The incisional feature covers an area of approximately $1.6 \mathrm{~km}^{2}$ and clearly reveals a spherical closed form on time slices (e.g. $2400 \mathrm{~ms}$; TWT; Fig. 10a). Due to its shape on the time slice, we interpret this feature to be possibly formed by bottom currents, locally in a narrow sea floor passage, e.g. between neighbouring salt diapirs.

\section{Maastrichtian and Danian unit}

The seismic facies of the base of the Maastrichtian (red line; Ma; Figs. 3, 6) unit is less variable than that of the base Campanian unit and consisting almost exclusively of a continuous and parallel reflector with a negative seismic polarity. The reflector at the near base Maastrichtian is located at a depth between 1430 and $3380 \mathrm{~m}$ and shows partly an erosional unconformity with onlap onto the top of the Campanian unit. The reflectivity is good to moderate, and the reflection pattern is mainly even and parallel (Fig. 6a). In places, a mounded and wavy reflection pattern at the base Maastrichtian is obvious. With the exception of halotectonic, no major deformation phase affected the sedimentary successions overlying the Campanian unit. We suggest that these sediments represent mainly pelagic deposits, as proposed earlier by Surlyk et al. (2008). The internal geometry of the unit is dominated in the southern study area by a concordant layering of Maastrichtian sediments with high amplitudes (Fig. 6c). Isolated bands of parallel and highamplitude reflectors can be traced in large parts of the study area (Fig. 6). Towards the north-west, the seismic facies of the unit varies between discontinuous and continuous reflections with low amplitudes (Fig. 6a). In the central Entenschnabel area, the internal geometry is in places not imaged due to a transparent and locally chaotic fill with low amplitudes (Fig. 6b). Up section U-, V-, W-, and tabularshaped incisions cut from the top into older Maastrichtian sediments and are more frequent and incised (Fig. 11). Figure 11 illustrates the results of a detailed, reflection-based interpretation of one $\mathrm{U}$ - to $\mathrm{V}$-shaped erosional reflector in 
Fig. 10 a A rounded feature possibly formed by bottom currents in a narrow sea floor passage. b The system of NNW-SSE-oriented incisions is located between two salt diapirs. Incisions correlate with a rounded shape visible on the time slice at a depth of $2400 \mathrm{~ms}$ [TWT] within the central part of the Entenschnabel area. c Seismic cross sections indicate the structures incision induced by erosional truncation of the immediately underlying sediments characterised by an 'onlap' fill facies
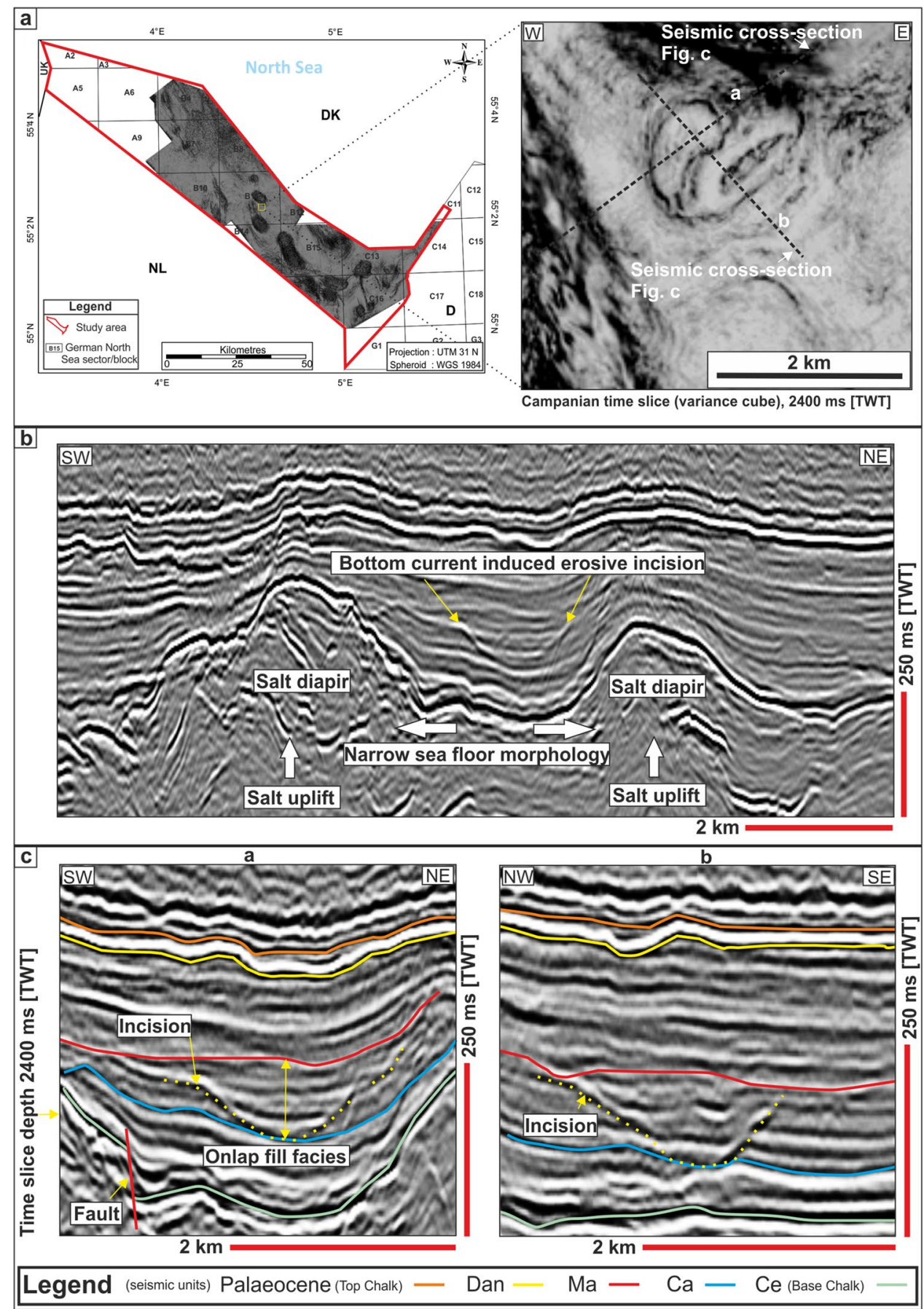

the eastern flank of the salt diapir Bettina Ost (Fig. 1b). The erosional truncation consists of two interconnected incisions showing a partly diffuse and onlap fill facies. In the time slice (variance $2390 \mathrm{~ms}$; TWT; Fig. 11), the incisions correspond to a pair of sharp, parallel-trending, slightly sinuous to almost linear variance attribute features that extend mainly in a NNE-SSW direction over a length between 1.6 and $2.6 \mathrm{~km}$ with an incisional depth of approximately $150 \mathrm{~m}$. Due to their cross-sectional shapes and their forms on the time slice, these features can be interpreted as an incised low sinuosity channels or channel segments which were presumably formed by gravity-driven deep-water turbidite systems.

An example of mass-transport deposition in the Maastrichtian unit is located in the central Entenschnabel, close to the southern flank of the salt diapir Birgit (Figs. 1b, 12a). The base of the incisional feature represents a high-amplitude reflection pattern showing a tabular cross section. 


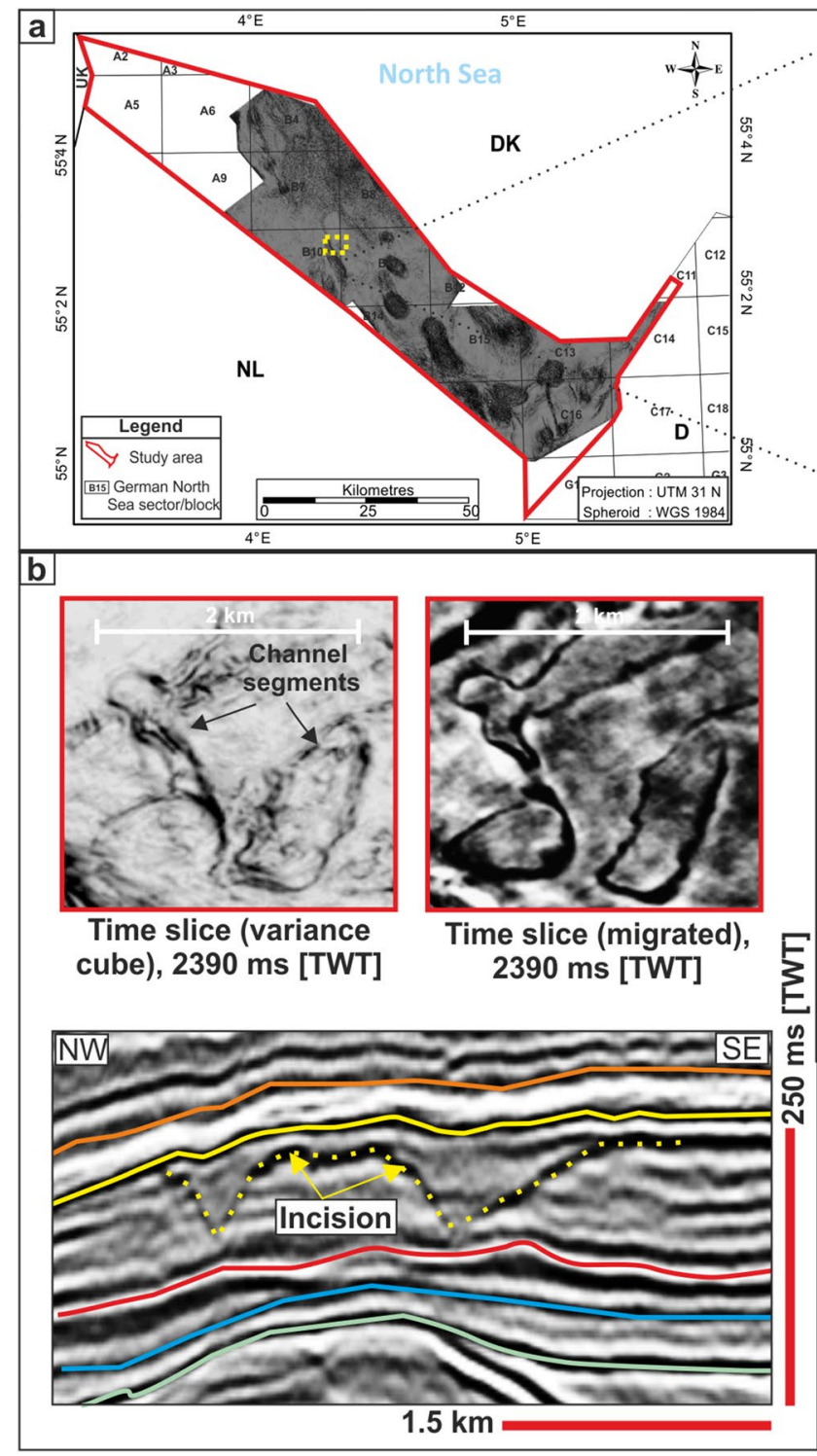

Fig. 11 a Channel or channel segments range from straight to a moderate sinuosity. b Incisions of channels in the upper part of the Maastrichtian unit are more distinct than those detected within the Turo-

The observed structure is about $5 \mathrm{~km}$ long, $4.5 \mathrm{~km}$ wide, approximately $100 \mathrm{~m}$ thick and encompasses Maastrichtian and Danian units (Fig. 12b). The main complex has a volume of approximately $4.5 \mathrm{~km}^{3}$. Local deformations at the incision's base and listric structures at the lateral margins are observed. Distinct lateral margins are imaged on the time slice (2200 ms; TWT) at approximately $2360 \mathrm{~m}$ depth (Fig. 12a). The internal reflection geometry suggests that this sediment body remained undeformed in large parts during mass transport and was moved in north-westward direction over a short distance. These observations may provide evidences for a slide complex. The slope failure was initiated at the flank of the illustrated Birgit diapir and

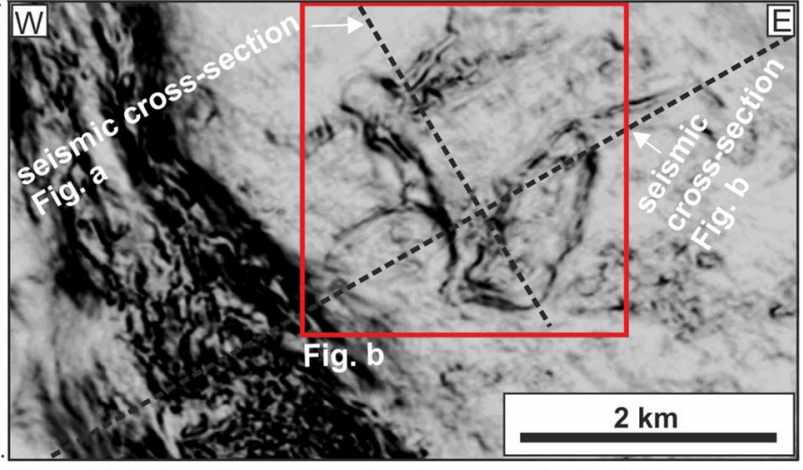

Maastrichtian time slice (variance cube), 2390 ms [TWT]
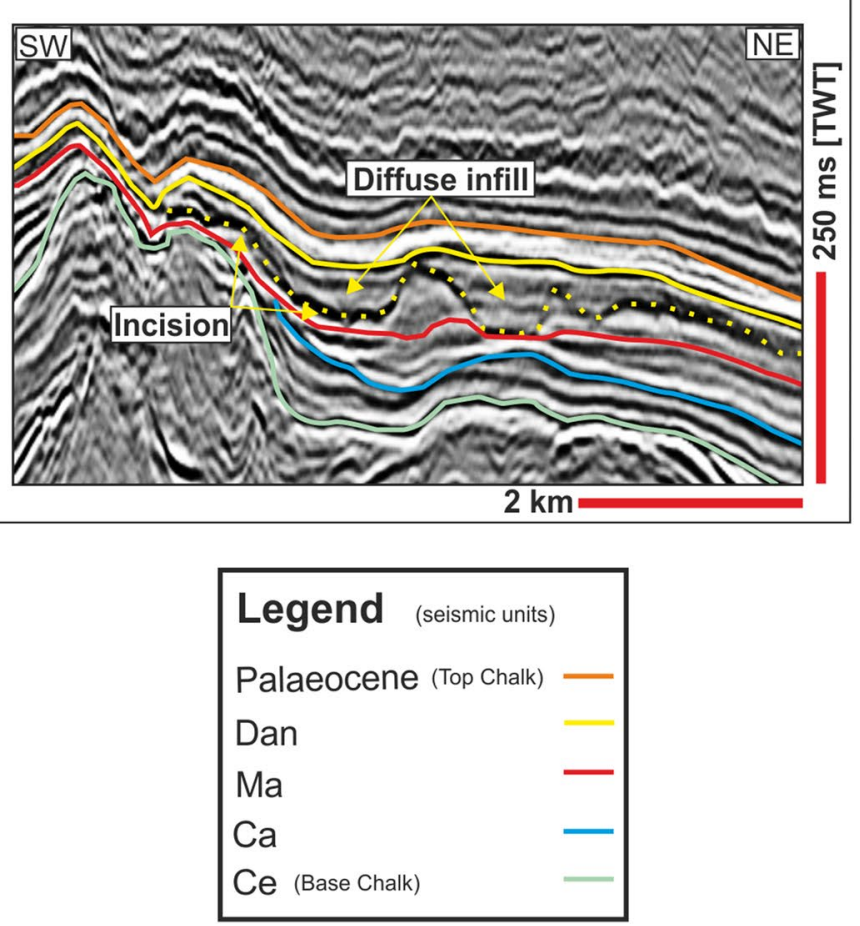

nian-Santonian unit. Encountered channel shifts from a NNE-SSW orientation to a NNW-SSE direction. The reflector displays an incisional depth of approximately up to $150 \mathrm{~m}$

must have occurred at the end of the Danian, just before the deposition of the first Palaeogene siliciclastic sediments which indicate the first undisturbed reflections above the slide complex. However, adjacent areas east- and westward of the lateral margins display a more chaotic seismic facies (Fig. 12a).

A conspicuously irregular positive reflection (Fig. 13) is visible above the Turonian-Santonian slump complexes and Campanian sediments forming a remarkable erosional incision. This reflection pattern is present within the Maastrichtian unit on the south-westernmost flank of the German Central Graben and can be extended towards the west into the Dutch Central Graben (Fig. 13a). The reflection 


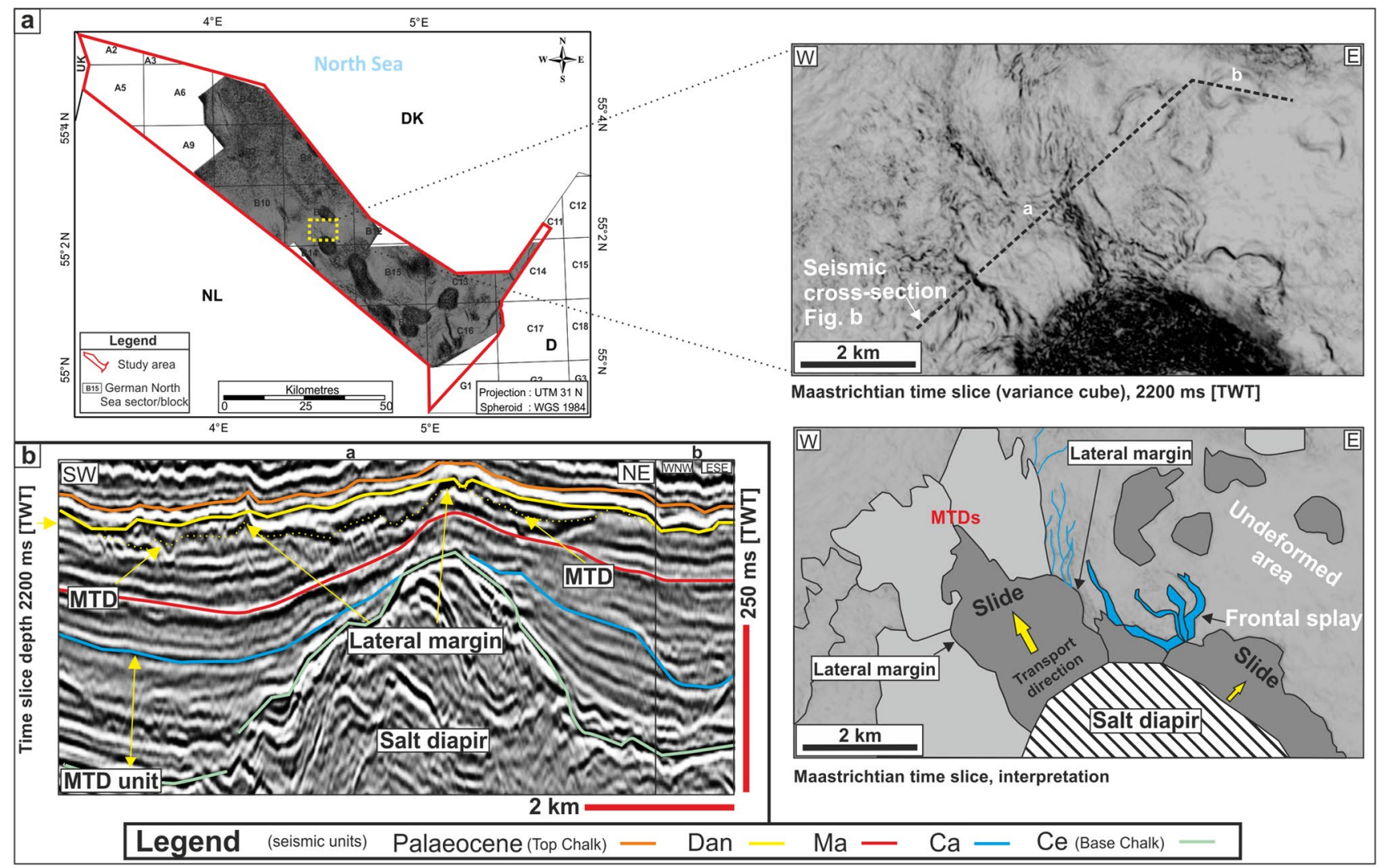

Fig. 12 a Distinct lateral margins of a relocated slide complex on a time slice (variance cube) at a depth of $2200 \mathrm{~ms}$ (TWT; approximately $2360 \mathrm{~m}$ ) are visible in the central Entenschnabel. b The base of the incision represents a high-amplitude reflection pattern showing

locally forms a significant onlap and irregular surface that cuts into and follows sedimentary bedding (Fig. 13b). Continuous and parallel reflections above show intermediate to high amplitudes. Similar reflection patterns were described elsewhere in the Dutch North Sea sector by Van der Molen et al. (2005). The reflector (approximately $15 \mathrm{~km}^{2}$ ) displays an incisional depth of approximately up to $100 \mathrm{~m}$ (Fig. 13b).

This reflector represents an almost perpendicular cut across the top of the Turonian-Santonian MTDs which is in this case oriented in a NE direction. The basal features are interpreted as erosional furrows or scours leaving an extremely irregular surface (Fig. 13). These features might have been formed by downslope-travelling mass flows such as erosive turbidity currents.

The base Danian (yellow line; Dan; Figs. 3, 6) is the uppermost unit recognised in the Chalk Group. In seismic cross sections, the base Danian represents one of the prominent reflectors occurring in the uppermost Chalk Group. In the south of the study area, the base Danian consists of a parallel and continuous reflector with high amplitudes (Fig. 6c). Towards the north-west, the seismic facies a tabular cross-sectional shape. The observed structure is about $5 \mathrm{~km}$ long, $4.5 \mathrm{~km}$ wide, approximately $100 \mathrm{~m}$ thick and encompasses the Maastrichtian unit. The main complex has a volume of approximately $4.5 \mathrm{~km}^{3}$

changes into a low-amplitude reflection pattern (Fig. 6a, b). The Danian was deposited under similar conditions as the upper Maastrichtian unit. The Danian unit shows mainly parallel and continuous reflections with high amplitudes. However, this unit is too thin to allow a clear recognition of an internal geometry, but in places in the top of this unit, mounded reflection patterns are developed.

\section{Discussion}

\section{Seismic observations}

Interpretation of 3D seismic reflection data proves that the North Sea Chalk in the Central Graben offshore Germany contains various types of MTDs.

Many of the observed seismic discontinuity features were found in areas affected by Late Cretaceous salt and inversion tectonic activity in the German Central Graben. This indicates a strong influence of tectonic processes on sediment deposition and might explain their present-day occurrence of discontinuous and chaotic seismic images 


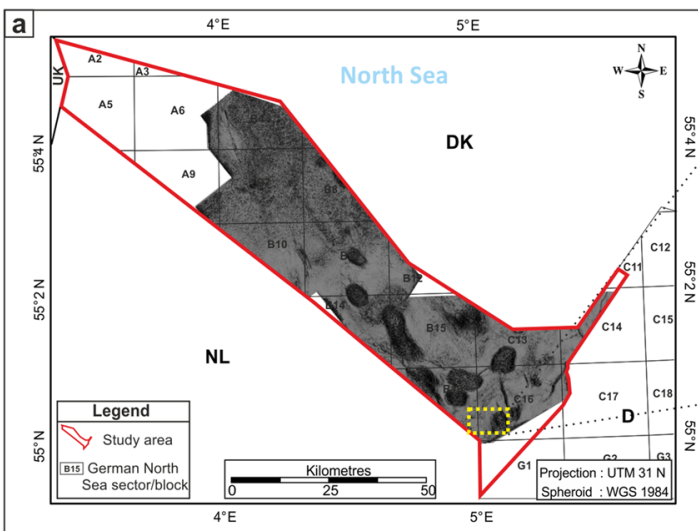

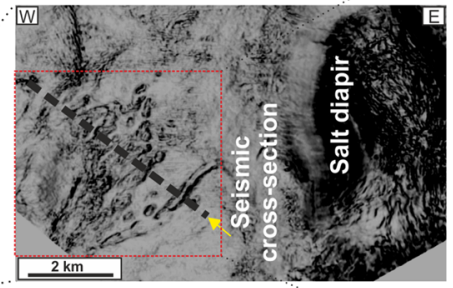

Turonian-Santonian time slice, (variance cube), $2110 \mathrm{~ms}$ [TWT]
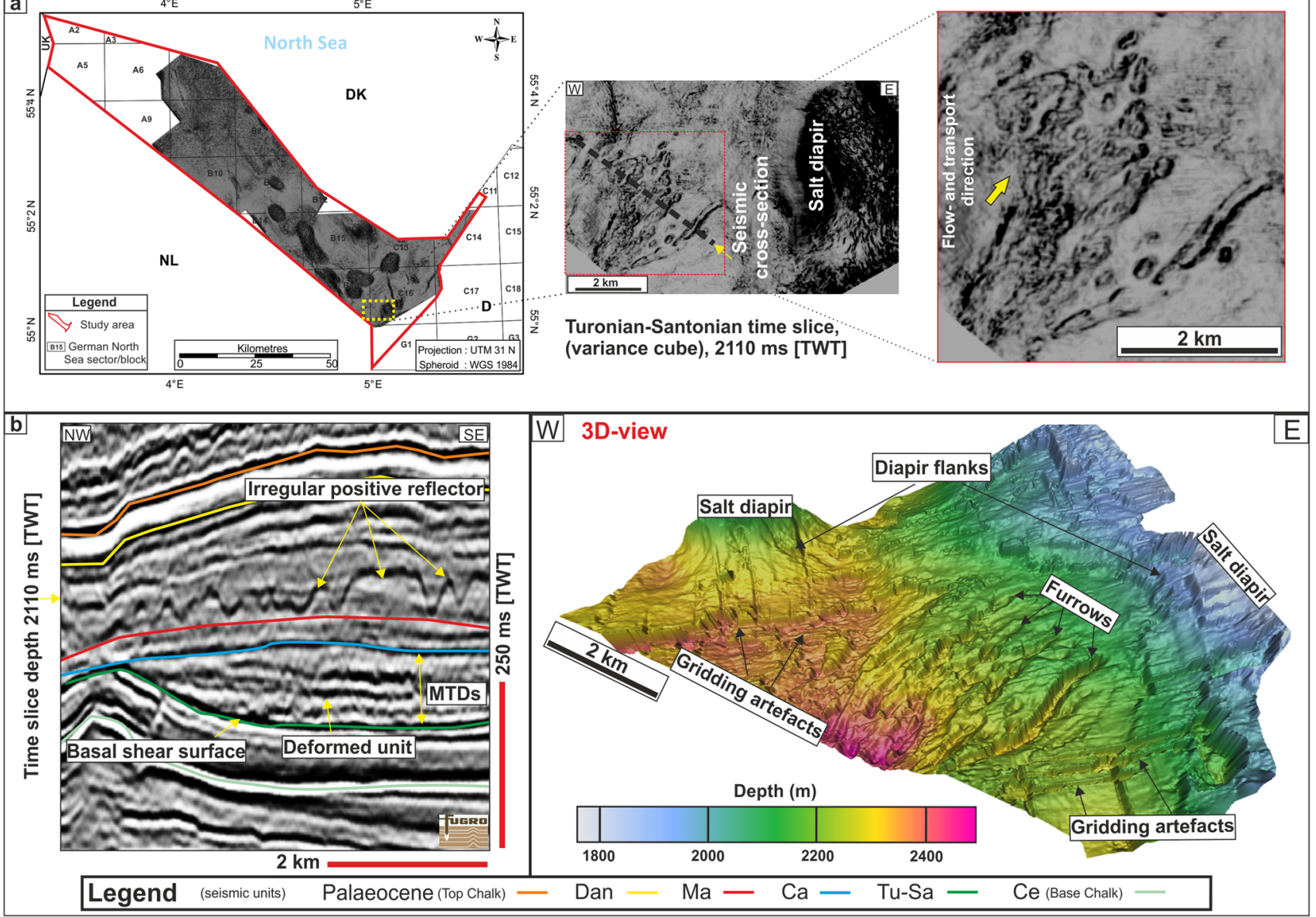

Fig. 13 a A conspicuously irregular reflector is visible above the Turonian-Santonian slump complexes and Campanian sediments forming a remarkable erosional incision. The reflection locally forms a significant onlap and irregular surface that cuts into and follows sedimentary bedding. Continuous and parallel reflections above show intermediate to high amplitudes. The reflector (approximately $15 \mathrm{~km}^{2}$ ) displays an incisional depth of approximately up to $100 \mathrm{~m}$. The basal features indicate furrows or scours formed as a result of downslope-travelling erosive turbidity currents

appears that relocation of chalk sediments was governed by downslope-travelling turbidity flows within the German Central Graben.

In the study area, MTDs interpreted as slumps internally consist of deformed strata, typically showing chaotic configurations and highly disrupted seismic reflections. The formation style, internal thrusts and the associated basal shear horizon are observations that allow to interpret these complexes as intra-chalk slump complexes. The occurrence of significant intra-chalk slump complexes is documented for the first time within the Entenschnabel area (Fig. 7) and fits well to interpretations in the Dutch and Danish North Sea sectors (Van der Molen et al. 2005; Back et al. 2011). In places, headwall scarps of slope failures are imaged on seismic profiles, but these might be locally often indistinct due to the post-depositional salt tectonics. Contrary to slump complexes, slide sheets represent downslope movements of internally undeformed sediment masses (Kennedy 
1987; Frey-Martínez et al. 2006; Lee et al. 2007) which were transported over short distances (Van der Molen et al. 2005; Fig. 12). Their 3D geometry clearly shows that this sediment body coherently moved in a north-westward direction caused by the increased slope gradient at the northern flank of Birgit salt diapir (Figs. 1b, 12).

Further south-west of the Entenschnabel area on the Schillgrund High a major channel system is visible formed by erosion due to powerful bottom currents. The channel trends most likely from the NW towards the SE as described by Surlyk et al. (2008). By tracing the northeastern extension of this channel system into the Entenschnabel, we found reflection patterns in our 3D seismic data similar to those on the Schillgrund High. These seismic responses correlate with the structure mapped in the southwesternmost part of the study area (Fig. 13). In seismic cross sections, this feature reflects a significant onlapping and irregular surface showing axial lows and highs which are interpreted as erosive furrows or scours (Fig. 13b). Erosional scours at the bases of mass flows are indeed a recognised feature of MTDs (Posamentier and Kolla 2003; Moscardelli et al. 2006; Lee et al. 2007; Posamentier and Martinsen 2011). Scours observed are located above the Turonian-Santonian slumps and are interpreted to represent remnants of strata removed by erosive, possibly highenergy SW-NE-oriented turbidity currents that transported the bulk of their sediment farther downslope. These erosive currents eroded deeply into previously deposited sediments. Undisturbed material preserved above the irregular surface seems to be filled from a SW direction indicated by onlapping reflection terminations. However, it cannot be excluded that striking linearity of scours that are commonly observed at the bases of MTDs forms as a result of laminar rather than turbulent currents that characterise these flows (Posamentier and Martinsen 2011). Assuming only the feature's shape on the time slices (variance), this could also be indicative for MTDs more likely a slide complex that reflects a downslope movement of chalk sediments from a $\mathrm{SW}$ direction towards the NE. The structural shape on the time slice (Fig. 13) is comparable to the Lower Cretaceous Fish Creek Slide in northern Alaska which is characterised by axial lows and highs (Homza 2004).

The variety of cross-sectional geometries ranging from U-, V- and W-shaped to tabular incisions can be explained by erosional truncation of the underlying strata (Fig. 2) resulting from sediment transport systems, e.g. channels. Such phenomena have been previously described elsewhere in the North Sea Central Graben (Van der Molen et al. 2005; Back et al. 2011). An essential part of recent studies on dynamic depositional systems during the development of the North Sea Chalk underlines the influence of powerful, long-lived, contour-parallel bottom currents for the formation of syn-sedimentary intra-chalk stratal irregularities and thus of submarine channel geometries (Lykke-Andersen and Surlyk 2004; Surlyk and Lykke-Andersen 2007; Surlyk et al. 2008; Esmerode et al. 2008). Because of the limited geometry solution in 2D seismic data, some elongated incisions or depressions were formerly interpreted as channels related to contour-parallel bottom currents (Korstgård et al. 1993; Surlyk and Lykke-Andersen 2007; Surlyk et al. 2008; Esmerode and Surlyk 2009).

It is important that orientations of the interpreted channel systems vary throughout the study area. Channels of the Turonian-Santonian interval trend into a NNW-SSE (Figs. 7, 8) direction. Encountered channel system in the Maastrichtian unit shifts from a NNE-SSW orientation to a NNW-SSE direction (Fig. 11b). In the south-westernmost study area, trends in a north-easterly direction are visible. These observations contradict contour-parallel bottom currents as the mechanism for the formation of submarine channel systems in this study (Fig. 13).

A network of shallow distributary channels (channelised lobes) or frontal splay complexes sensu Posamentier (2003) and Posamentier and Kolla (2003) is classified (Fig. 9) at gradient breaks in the south-easternmost part of the Entenschnabel. Depositional lobes are identified at the terminations of channel systems indicating the direction of their mass flows (Figs. 8, 9). Also here the orientation of the channels varies in the study area where sediment was transported from the eastern and northern flank of Charlotte salt diapir (Fig. 1b) towards the north-east and northwest into the depressions of the German Central Graben area (Fig. 9). These recognitions led us to conclude that the channels were formed by channelised turbidity systems (e.g. Catuneanu 2003; Posamentier and Kolla 2003; Lee et al. 2007; Kolla et al. 2007; Posamentier and Martinsen 2011). According to Catuneanu (2003), splay complexes generally correspond to the place where energy of a flow decreases to a phase that releases the accumulation of the bulk of its sediment load. The transition from a channel to a frontal splay complex is probably associated with a marked reduction in, e.g., channel width, channel depth and channel sinuosity (Posamentier and Kolla 2003).

The observation of elongate features in $3 \mathrm{D}$ seismic data revealed that only around $60 \%$ of them are compatible with a channel origin (Figs. 8, 9, 10, 11, 12), much in the way as Tertiary depressions showing spherical closed forms, incompatible with channel systems (Andresen et al. 2008). The other percentage of features is related either to incisional slide complexes or presumably formed by bottom currents, in narrow passages, e.g. between neighbouring salt diapirs (Fig. 10; Esmerode et al. 2008). This is evident by the pronounced relief of the incisional feature covering the central Entenschnabel area (Fig. 10) which is clearly linked to salt diapirs displaying a closed form on the time slice incompatible with a gravity-driven, 
downslope-oriented turbidity origin (e.g. Fig. 8b). This feature is evident for bottom currents in response of pockmark formation comparable to those encountered in the Danish North Sea within the Chalk Group (Masoumi et al. 2014).

The morphology of the incisional features during the Campanian to Danian units differs from those developed in the Turonian-Santonian units as it looks closely related to the depth, width and slope angles of basal incisions. Up sections incisions reach depths of up to $150 \mathrm{~m}$, while the Turonian-Santonian incisions are less incised reaching depths of up to $15 \mathrm{~m}$. Measured slope gradients of incisional bases in the study area show considerable variability from $5^{\circ}$ to $29^{\circ}$ (Fig. 2). These recognitions can be used to ascertain whether chalk sediments were already lithified before erosional processes affecting the sea floor. By assuming an angle of repose between $30^{\circ}$ and $40^{\circ}$ for calcareous ooze according to Lee et al. (1994), this suggest that incisions within the study area were formed when the sediment was already semi-lithified to lithified. As mentioned by Van der Molen (2004), lithified chalk is often subject to mass movements in which chalk clasts are reshaped or broken up during transport.

The widespread lateral extent, quantity, seismic character and the variability in transport directions of masstransport complexes (i.e. slides, slumps and channels) as interpreted in this study suggest a critical re-evaluation of the main triggering mechanisms for the deposition of the North Sea Chalk. In the study area, gravity-driven masstransport processes are interpreted as the major mechanism for the redistribution of sediments (mass-transport movements). This is in accordance with the extent of syndepositional uplift particularly within the German Central Graben. Two main mechanisms are considered as potential trigger for slope failure initiation: salt diapirism and Late Cretaceous inversion tectonics. Diapirism in the study area is characterised by vertical movement of the sedimentary section above the Zechstein salt and the subsidence of rimsynclines around and between salt structures (Arfai et al. 2014). Salt uplift primarily leads to tilting or local steepening of the sea floor and an increasing slope angle (Figs. 7, $8,9)$. Figure 4 illustrates a synchronous salt diapirism to chalk deposition as revealed by increases in thicknesses in rim-synclines around salt diapirs. Inversion tectonics occur in compressional regimes (Figs. 6c, 7c) leading to reactivation of existing fault systems. In the German Central Graben, Triassic to Jurassic fault structures and Jurassic graben systems were inverted (Arfai et al. 2014). Tectonic inversion had a direct impact on Chalk Group deposition which changed from predominately pelagic during the Cenomanian to Turonian to a dominance of gravity flow deposition close to inverted zones during the Turonian to the Late Campanian. In areas where inversion tectonics affected the German Central Graben, e.g. the Schillgrund Fault, seismic responses similar to those in the vicinity of salt diapirs are visible (Fig. 8c). These seismic discontinuities are related to small-scale slump deposits and represent the reactivation of major fault structures during the deposition of the chalk in Turonian to Santonian times. In some cases, salt and inversion tectonics seem to act simultaneously which resulted in gravity-driven mass transports and removal of sediments in different flow directions (Figs. 6, 7, 8). During the Late Campanian, tectonic activity abated so that this chalk interval was characterised by higher reflection continuity with only minor disorganised seismic responses and gravity-driven MTDs.

In summary, the pronounced stratal discontinuity observed in the study area indicates that chalk sedimentation was locally dominated by submarine erosion and relocation (Fig. 14). The mass-transport systems encountered within the German Central Graben are not developed in the Cenomanian interval, but reach a maximum within the Turonian-Santonian unit and locally occur within the Campanian, Maastrichtian and Danian units reflecting the Late Cretaceous tectonic intensity during these geological stages (Fig. 14a-c). The majority of slumps and slides observed in the Entenschnabel are preserved alongside tectonically active inversion zones and in the vicinity of salt diapirs exhibiting that tectonically induced gravitational mass flow represents the main trigger for the redistribution of chalk sediment (Fig. 14a). Additionally, the geomorphology and architecture of elongated features interpreted as channels (Fig. 14a) suggest that these systems correspond to repeated gravity-driven turbulent flows that transported failed chalk material into the bathymetric lows of the German Central Graben. However, at the same stratigraphic level, there are also incisional features in seismic cross sections similar to channels with closed spherical shapes on time slices showing implications for bottom currents (Lykke-Andersen and Surlyk 2004; Surlyk and Lykke-Andersen 2007; Surlyk et al. 2008; Esmerode et al. 2008; Figs. 10, 14b). This let us finally to conclude that a complex interaction of Late Cretaceous inversion and salt tectonics, gravity-driven processes and sea floor bottom currents dominated chalk reworking and redeposition in the study area (Fig. 14a-c; Van der Molen et al. 2005; Back et al. 2011). The redeposited chalk can be observed as a highly variable depositional element within the North Sea Central Graben.

\section{Reservoir properties and hydrocarbon aspects}

After deposition, pelagic chalk was subjected to relocation by various gravity-driven mass-transport processes and thus can be protected from early porosity-reducing cementation processes and enhances thereby the reservoir quality (Schatzinger et al. 1985; Taylor and Lapré 1987; Bramwell et al. 1999; Anderskouv and Surlyk 2012). After transport 

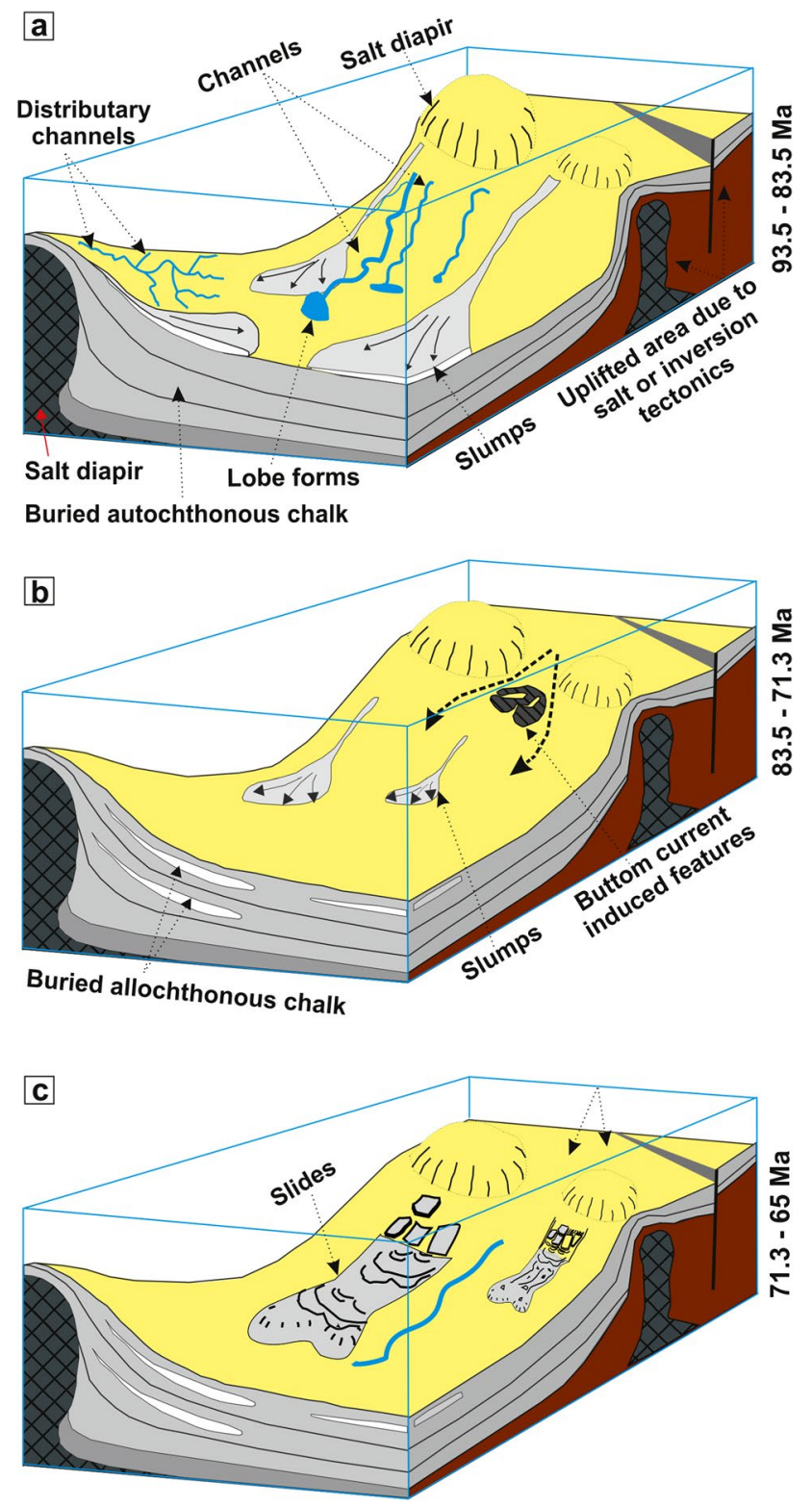

Fig. 14 Summary models of the depositional systems within the German Central Graben area interpreted from seismic reflection discontinuities and time slices in different stratigraphic levels. a During the Turonian-Santonian, the chalk interval is characterised by generally chaotic reflection patterns with few seismic dissemblance features interpreted as kilometre-scale slumps, isolated channels and distributary channel systems. Straight to sinuous channels and networks of channelised lobe systems were formed by downslope-travelling erosive turbidity flows. Gravity-driven MTDs are induced due to intense salt and inversion tectonics which resulted in the steepening and tilting of the sea floor. b During the Late Campanian, the remarkable tectonic activity abated so that the chalk interval is characterised by a continuous reflection pattern with only minor disorganised seismic responses and small-scale gravity-driven MTDs. Spherical-shaped features are induced probably as a result of sea floor bottom currents. c Seismic reflection discontinuity wanes during the Maastrichtian interval. Isolated MTDs such as slide sheets and only a few channel systems dominated the Maastrichtian sea floor morphology. Models are modified after Van der Molen et al. (2005) of the MTDs to a new site, bioturbation has no or only little time to act (Hardman 1982; Schatzinger et al. 1985). In this case, the formation of hard grounds can be reduced which enables a development of a rock with an estimated porosity at time of redeposition ranging between 50 and $55 \%$ and which will subsequently be buried beneath the next transported deposits (Hardman 1982). The best reservoir properties (e.g. porosities of up to $45 \%$; South Arne Field; Japsen et al. 2005) are found in the reworked chalk strata of the Tor and Ekofisk formations (Taylor and Lapré 1987; Underhill 1998). So it is not necessarily the case that redeposited chalk forms better reservoirs. Traps within the Chalk Group range from inversion-generated anticlines (e.g. the Valhall, Roar, Tyra and South Arne fields) over salt domes with some degree of inversion overprint (e.g. the Dan, Ekofisk and Svend fields) to salt diapirs (e.g. the Skjold and Harald fields; Vejbæk et al. 2007). Stratigraphic traps may also play a major role (e.g. the Halfdan and Adda fields; Vejbæk et al. 2007). Structural traps such as described by Vejbæk et al. (2007) are observed within the German Central Graben and provide additional reasons for the Chalk as a hydrocarbon reservoir. Danian and Maastrichtian chalk reservoirs preserved in the Central Graben are encountered in depths between 2930 and $3080 \mathrm{~m}$ sealed by thick overpressured Tertiary shales of regional extent (Moore 2001). After the Mesozoic fill of the Central Graben, subsequent accumulation of more than 2500 m sediments took place during the Cenozoic (Arfai et al. 2014). These sediments could act as a top seal for chalk reservoirs. Where the Chalk is characterised by overpressure such as within the Central Graben, it contains important hydrocarbon accumulations, e.g. the Ekofisk and Dan fields in the Norwegian and Danish sectors (Scholle 1977; Japsen 1998). In the North Sea Central Graben, the source rocks for the oil found in chalk reservoirs are frequently the organic-rich Upper Jurassic Kimmeridge Clay, separated from the chalk by a thick Lower Cretaceous shale sequence (Damtoft et al. 1986; Surlyk et al. 2003; Kubala et al. 2003; Beha et al. 2008). Oil generation of the Kimmeridge Clay started during Eocene to Early Miocene within the Central Graben area (Hardman 1982; Andresen et al. 2008).

The British part of the Central Graben contains isolated chalky hydrocarbon fields (Oakman and Partington 1998; Megson and Hardman 2001; Surlyk et al. 2003). Within the Dutch Central Graben, the 'Hanze Field' is one of two oil accumulations in the Chalk Group (Hofmann et al. 2002; Kombrink et al. 2012). The other oil accumulation was found in 2012 by the exploration well F17-10 (Kombrink et al. 2012). If MTDs are clay-free, the redeposited chalk has the potential to be an excellent reservoir (Hardman 1982). In the Entenschnabel area, Chalk Group sediments mainly consist of white chalk and chalky limestones which could be considered from a porosity perspective as 
potential hydrocarbon reservoirs. Due to the large oil discoveries in the North Sea and in the recent Lille John oil field (Danish North Sea), the question should be addressed whether the Kimmeridgian source rock facies extends southwards from the Danish sector into the German Central Graben (e.g. John Graben) where Upper Jurassic sediments reach maximum thicknesses and deepest burial (Arfai et al. 2014)? However, inferences whether the Chalk Group MTDs have been charged by Jurassic Kimmeridge Clay source rocks within the German Central Graben will require additional investigations.

\section{Conclusions}

3D seismic data, enabling to view data sets from different directions and using time slices, provide insights into the deformed intra-chalk successions and impacts of masstransport depositional elements within the German Central Graben area.

- Based on mapping and correlation of major unconformities which are tied to stratigraphic data at borehole locations, the Chalk Group in the Entenschnabel was subdivided into five seismic units. The subdivision enables a stratigraphic correlation of the Late Cretaceous morphological structures identified as MTDs.

- A broad spectrum of outer shapes and internal architectural elements, mostly related to erosional truncation of the immediately underlying sediments, was obtained from seismic cross sections. Time slices (variance cube) from 3D data provide evidence that in places incisions are characterised by spherical and elliptical shapes, inconsistent with a channel origin.

- The central and north-western realm of the Entenschnabel shows undeformed intra-chalk successions which are characterised by parallel to subparallel and continuous reflection patterns, reflecting depositional processes under relatively quiet tectonic conditions. In contrast, deposition of the Chalk Group within the German Central Graben is coincident with intense tectonic activity resulting in discontinuous and chaotic seismic facies. Such reflection patterns indicate redeposition of large sediment masses.

- Locally, slump complexes and slide sheets are encountered that are several kilometres in lateral extent. Slumps are identified in the Turonian-Santonian units, while slides are limited to the Maastrichtian-Danian units. Straight to sinuous channels and networks of channelised lobe systems were formed by downslopetravelling turbidity flows.

- The triggering mechanisms for mass-transport complexes in the Entenschnabel area are salt movement and tectonic uplift. A compressional tectonic regime led to basin inversion throughout the Late Cretaceous. The most significant inversion occurred from the post-Turonian until the Late Campanian.

- MTDs within the German Central Graben may exhibit good reservoir properties and thus form suitable reservoirs for hydrocarbons which could be charged by Upper Jurassic Kimmeridge Clay source rocks.

Acknowledgments The authors thank the German North Sea Consortium (GNSC; BEB Erdgas Erdöl, Wintershall Holding AG, RWE Dea AG, EWE AG), Fugro Multiclient Services AS (FMCS) and TGS-NOPEC for the permission to use their seismic data. We thank Dr. Thomas Pletsch and Dr. Lutz Reinhardt for their comments and suggestions which led to a revised edition of this manuscript. Personally thanked are the IJES-Editors Prof. Dr. Wolf Christian Dullo as the Editor-in-Chief and Dr. Jürgen Grötsch. We gratefully acknowledge the reviewers Dr. Stefan Back, Dr. Ramon Loosveld and Dr. Allard van der Molen for their corrections, comments and suggestions that significantly helped to improve an earlier version of the manuscript.

Open Access This article is distributed under the terms of the Creative Commons Attribution 4.0 International License (http://creativecommons.org/licenses/by/4.0/), which permits unrestricted use, distribution, and reproduction in any medium, provided you give appropriate credit to the original author(s) and the source, provide a link to the Creative Commons license, and indicate if changes were made.

\section{References}

Anderskouv K, Surlyk F (2012) The influence of depositional processes on the porosity of chalk. J Geol Soc Lond 169:311-325. doi:10.1144/0016-76492011-079

Andresen KJ, Huuse M, Clausen OR (2008) Morphology and distribution of Oligocene and Miocene pockmarks in the Danish North Sea-implications for bottom current activity and fluid migration. Basin Res 20:445-466

Arfai J, Jähne F, Lutz R, Franke D, Gaedicke C, Kley J (2014) Late Palaeozoic to Early Cenozoic geological evolution of the northwestern German North Sea (Entenschnabel). New results and insights. Neth J Geosci. doi:10.1017/njg.2014.22

Back S, Van Gent H, Reuning L, Grötsch J, Niederau J, Kukla P (2011) 3D-seismic geomorphology and sedimentology of the Chalk Group, Southern Danish North Sea. J Geol Soc Lond 168:393-405

Bailey H, Gallagher L, Hampton M, Krabbe H, Jones B, Jutson D, Moe A, Nielsen EB, Petersen NW, Riis F, Sawyer D, Sellwood B, Strand T, Øverli PE, Øxnevad I (1999) Joint chalk research phase V: a joint chalk stratigraphic framework. Norwegian Petroleum Directorate (NPD), Stavanger

Barton P, Wood R (1984) Tectonic evolution of the North Sea Basin: crustal stretching and subsidence. Geophys J R Astron Soc 79:987-1022

Beha A, Thomsen OR, Littke R (2008) Thermal history, hydrocarbon generation and migration in the Horn Graben in the Danish North Sea: a 2D basin modelling study. Int J Earth Sci (Geol Rundsch) 97:1087-1100. doi:10.1007/s00531-007-0247-2

Bramwell NP, Caillet G, Meciani L, Judge N, Green A, Adam P (1999) Chalk exploration, the search for a subtle trap. In: Fleet AJ, Boldy SAR (eds) Petroleum geology of Northwest Europe: proceedings of the 5th conference. The Geological Society of London, London, pp 911-937 
Bull S, Cartwright J, Huuse M (2009) A review of kinematic indicators from mass-transport complexes using 3D-seismic data. Mar Pet Geol 26:1132-1151. doi:10.1016/j.marpetgeo.2008.09.011

Catuneanu O (2003) Sequence stratigraphy of clastic systems. Geological Association of Canada, St. John's Newfoundland

Catuneanu O, Galloway WE, Kendall GSC, Miall AD, Posamentier HW, Strasser A, Tucker ME (2011) Sequence stratigraphy: methodology and nomenclature. Newsl Stratigr 44:173-245

Damtoft K, Andersen C, Thomsen E (1986) Prospectivity and hydrocarbon plays of the Danish Central Trough. In: Brooks J, Glennie KW (eds) Petroleum geology of North West Europe. Graham and Trotman, London, pp 403-418

Esmerode EV, Surlyk F (2009) Origin of channel systems in the Upper Cretaceous Chalk Group of the Paris Basin. Mar Pet Geol 26:1338-1349

Esmerode EV, Andersen HL, Surlyk F (2008) Interaction between bottom currents and slope failure in the Late Cretaceous of the southern Danish Central Graben, North Sea. J Geol Soc 165:55-72

Frey-Martínez J, Cartwright J, Hall B (2005) 3D-seismic interpretation of slump complexes: examples from the continental margin of Israel. Basin Res 17:83-108

Frey-Martínez J, Cartwright J, James D (2006) Frontally confined versus frontally emergent submarine landslides: a 3D-seismic characterization. Mar Pet Geol 23:585-604

Gennaro M, Wonham JP, Gawthorpe R, Sælen G (2013) Seismic stratigraphy of the Chalk Group in the Norwegian Central Graben, North Sea. Mar Pet Geol 45:236-266

Graversen O (2002) A structural transect between the central North Sea Dome and the South Swedish Dome: Middle Jurassic-Quaternary uplift/subsidence reversal and exhumation across the eastern North Sea Basin. In: Doré AG, Cartwright J, Stoker MS, Turner JP, White N (eds) Exhumation of the North Atlantic Margin: timing, mechanisms and implications for petroleum exploration, vol 196. Geological Society of London, Special Publications, London, pp 67-83

Graversen O (2006) The Jurassic-Cretaceous North Sea Rift Dome and associated basin evolution. In: American Association of Petroleum Geologists annual convention, Calgary, AB, June $19-22$

Hancock JM (1975) The petrology of the Chalk. Proc Geol Assoc 86(4):499-535

Hardman RFP (1982) Chalk reservoirs of the North Sea. Bull Geol Soc Den 30:119-137

Hofmann AP, Price A, Kaffenberger G, Godderij RRGG, Simpson M (2002) Hanze chalk oil field - the Chalk pearl in the Dutch North Sea. In: 64th conference and technical exhibition-26-30 May. European Association of Geoscientists and Engineers, Florence (abstract), p 4

Homza TX (2004) A structural interpretation of the Fish Creek Slide (Lower Cretaceous), northern Alaska. Am Assoc Pet Geol 88:256-278

Japsen P (1998) Regional velocity-depth anomalies, North Sea Chalk: a record of overpressure and Neogene uplift and erosion. AAPG Bull 82:2031-2074

Japsen P, Bruun A, Fabricius IL, Mavko G (2005) Identification of hydrocarbons in chalk reservoirs from surface seismic data: South Arne field, North Sea. Geol Surv Den Greenl Bull 7:13-16

Jeppesen MW (1994) Geological steering of horizontal wells in chalk reservoirs-examples from the Danish North Sea. Bull Geol Soc Den 41:138-144

Kennedy WJ (1987) Sedimentology of Late Cretaceous-Palaeocene chalk reservoirs, North Sea Central Graben. In: Brooks J, Glennie KW (eds) Petroleum geology of north-west Europe. Graham and Trotman, London, pp 469-480
Kolla V, Posamentier HW, Wood LJ (2007) Deep-water and fluvial sinuous channels - characteristics, similarities and dissimilarities, and models of formation. Mar Pet Geol 24:388-405

Kombrink H, ten Veen JH, Geluk MC (2012) Exploration in the Netherlands, 1987-2012. Neth J Geosci-Geol Mijnb 91(4):403-418

Kominz MA, Browning JV, Miller KG, Sugarman PJ, Mizintseva S (2008) Late Cretaceous to Miocene sea level estimates the New Jersey and Delaware coastal plain coreholes: an error analysis. Basin Res 20:211-226

Korstgård JA, Lerche I, Mogensen TE, Thomsen RO (1993) Salt and fault interactions in the northeastern Danish Central Graben: observations and interferences. Bull Geol Soc Den 40:197-255

Kubala M, Bastow M, Thompson S, Scotchman I, Oygard K (2003) Geothermal regime, petroleum generation and migration. In: Evans D, Graham C, Armour A, Bathurst P (eds) The millennium atlas: petroleum geology of the central and Northern North Sea. The Geological Society of London, London, pp 289-315

Lee HJ, Torresan ME, McArthur W (1994) Stability of submerged slopes on the flanks of the Hawaiian, Islands, a simplified approach. US Geological Survey open-file report 94-638, pp 13-14

Lee HJ, Locat J, Desgagnes P, Parsons JD, McAdoo BG, Orange DL, Puig P, Wong FL, Dartnell P, Boulanger E (2007) Submarine mass movements on continental margins. In: Nittrouer $\mathrm{CA}$, Austin JA, Field ME, Kravitz JH, Syvitski JPM, Wiberg PL (eds) Continental margin sedimentation: from sediment transport to sequence stratigraphy. Blackwell, Oxford, pp 213-274

Liboriussen J, Ashton P, Tygesen T (1987) The tectonic evolution of the Fennoscandian border zone in Denmark. In: Ziegler PA (ed) Compressional intra-plate deformations in the Alpine Foreland. Elsevier, Amsterdam, pp 21-29

Lykke-Andersen H, Surlyk F (2004) The Cretaceous-Palaeogene boundary at Stevns Klint, Denmark: inversion tectonics or sea floor topography? J Geol Soc 161:343-352

Masoumi S, Reuning L, Back S, Sandrin A, Kikla PA (2014) Buried pockmarks on the Top Chalk surface of the Danish North Sea and their potential significance for interpreting palaeocirculation patterns. Int J Earth Sci 103:563-578

Megson JB (1992) The North Sea Chalk play: examples from the Danish Central Graben. In: Hardman RFP (ed) Exploration Britain: geological insights for the next decade. Geological Society, London, Special Publication 67, pp 247-282

Megson J, Hardman R (2001) Exploration for and development of hydrocarbons in the Chalk of the North Sea: a low permeability system. Pet Geosci 7:3-12

Menning M (2012) Explanatory notes to the stratigraphic table of Germany Compact. Erläuterung zur Stratigraphischen Tabelle von Deutschland Kompakt 2012. Zeitschrift der Deutschen Gesellschaft für Geowissenschaften 163(4):385-409

Mitchum RM Jr, Vail PR, Sangree JB (1977) Seismic stratigraphy and global changes of sea-level, part 6: stratigraphic interpretation of seismic reflection patterns in depositional sequences. In: Payton C (ed) Seismic Stratigraphy Applications to Hydrocarbon Exploration. American Association of Petroleum Geologist Bulletin, Tulsa, pp 117-133

Mogensen TE, Jensen LN (1994) Cretaceous subsidence and inversion along the Tornquist Zone from Kattegat to the Egersund Basin. First Break 12:211-222

Moore CH (2001) Carbonate reservoirs-porosity evolution and diagenesis in a sequence stratigraphic framework. Developments in sedimentology, vol 55. Elsevier, Amsterdam

Moscardelli L, Wood L, Mann P (2006) Mass-transport complexes and associated processes in the offshore area of Trinidad and Venezuela. AAPG Bull 90(7):1059-1088 
Oakman CD, Partington MA (1998) Ch. 9. Cretaceous. In: Glennie KW (ed) Petroleum geology of the north Sea. Blackwell, Oxford, pp 294-349

Posamentier HW (2003) Depositional elements associated with a basin floor channel-levee system: case study from the Gulf of Mexico. Mar Pet Geol 20:677-690

Posamentier HW, Kolla V (2003) Seismic geomorphology and stratigraphy of depositional elements in deep-water settings. J Sediment Res 73:367-388

Posamentier HW, Martinsen OJ (2011) The character and genesis of submarine mass-transport deposits: insights from outcrop and 3D seismic data. In: Shipp RC, Weimer P, Posamentier HW (eds) Mass-transport deposits in deepwater settings. Society for Sedimentary Geology, Special Publication 96, pp 7-38

Schatzinger RA, Feazel CT, Henry WE (1985) Evidence of resedimentation in Chalk from the Central Graben, North Sea. In: Crevello PD, Harris PM (eds) SEPM core workshop no. 6. Society of Economic Palaeonological Mineralogists, New Orleans, pp 342-389

Scholle PA (1977) Chalk diagenesis and its relation to petroleum exploration: oil from chalks, a modem miracle? Am Assoc Pet Geol Bull 61:982-1009

Schulz-Ela D, Jackson PA, Vendeville BC (1993) Mechanics of active salt diapirism. Tectonophysics 228:275-312

Sclater JG, Christie PAF (1980) Continental stretching: an explanation of the post-mid-Cretaceous subsidence of the Central North Sea Basin. J Geophys Res 85(B7):3711-3739

Surlyk F, Lykke-Andersen H (2007) Contourite drifts, moats and channels in the Upper Cretaceous chalk of the Danish Basin. Sedimentology 54:405-422

Surlyk F, Dons T, Clausen CK, Higham J (2003) Upper Cretaceous. In: Evans D, Graham C, Armour A, Bathurst P (eds) The Millennium Atlas: petroleum geology of the central and Northern North Sea. Geological Society of London, London, pp 213-233

Surlyk F, Jensen SK, Engkilde M (2008) Deep channels in the Cenomanian-Danian Chalk Group of the German North Sea sector: evidence of strong constructional and erosional bottom currents and effect on reservoir quality distribution. Am Assoc Pet Geol Bull 92:1565-1586

Taylor SR, Lapré JF (1987) North Seachalk diagenesis its effects on reservoir location and properties. In: Brooks J, Glennie KW (eds) Petroleum geology of North West Europe. Graham and Trotman, London, pp 483-495
Underhill JR (1998) Jurassic. In: Glennie KW (ed) Petroleum geology of the North Sea: basic concepts and recent advances. Blackwell Science Geology and Petroleum Geology, Oxford, pp 245-293

Underhill JR, Partington MA (1993) Jurassic thermal doming and deflation in the North Sea: implications of the sequence stratigraphic evidence. In: Parker JR (ed) Petroleum geology of Northwest Europe: proceedings of the 4th conference. The Geological Society of London, London, pp 337-345

Van Adrichem Boogaert HA, Kouwe WFP (1994) Stratigraphic nomenclature: section $\mathrm{H}$-Upper Cretaceous and Danian (Chalk Group), Mededelingen Rijks Geologische Dienst 50. Rijks Geologische Dienst, Haarlem

Van der Molen AS (2004) Sedimentary development, seismic stratigraphy and burial compaction of the Chalk Group in the Netherlands North Sea area. Dissertation, University of Utrecht

Van der Molen AS, van Heel HWD, Wong ThE (2005) The influence of tectonic regime on Chalk deposition: examples of the sedimentary development and 3D-seismic stratigraphy of the Chalk Group in the Netherlands offshore area. Basin Res 17:63-81

Vejbæk OV, Andersen C (2002) Post mid-Cretaceous inversion tectonics in the Danish Central Graben-regionally synchronous tectonic events. Bull Geol Soc Den 49:129-144

Vejbæk OV, Bidstrup T, Britze P, Erlström M, Rasmussen ES, Sivhed U (2007) Chalk depth structure maps, central to eastern North Sea, Denmark. Geol Surv Den Greenl Bull 13:9-12

Vejbæk OV, Andersen C, Dusar M, Herngreen GFW, Krabbe H, Leszczyński K, Lott GK, Mutterlose J, Van der Molen AS (2010) Cretaceous. In: Doornenbal JC, Stevenson AG (eds) Petroleum geological atlas of the Southern Permian Basin Area. EAGE b.v., Houten, pp 195-209

Watts NL, Lapre JF, Vanschijndelgoester FS, Ford A (1980) Upper Cretaceous and Lower Tertiary Chalks of the Albuskjell Area, North-Sea-deposition in a slope and a base-of-slope environment. Geology 8:217-221

Ziegler PA (1990) Geological atlas of Western and Central Europe, 2nd edn. Shell Internationale Petroleum Maatschappij B.V., Bath 